\title{
Targeting phytoprotection in the COVID-19-induced lung damage and associated systemic effects-the evidence-based 3PM proposition to mitigate individual risks
}

\author{
Alena Liskova ${ }^{1} \cdot$ Lenka Koklesova $^{1} \cdot$ Marek Samec $^{1} \cdot$ Basma Abdellatif $^{2} \cdot$ Kevin Zhai $^{2} \cdot$ Manaal Siddiqui $^{2} \cdot$ \\ Miroslava Šudomová ${ }^{3}$ - Sherif T.S. Hassan ${ }^{4}$ • Erik Kudela $^{1} \cdot$ Kamil Biringer $^{1}$ • Frank A. Giordano ${ }^{5} \cdot$ Dietrich Büsselberg $^{2}$ • \\ Olga Golubnitschaja ${ }^{6} \cdot$ Peter Kubatka $^{7}$
}

Received: 21 June 2021 / Accepted: 3 July 2021 / Published online: 3 August 2021

(C) The Author(s) 2021

\begin{abstract}
The risks related to the COVID-19 are multi-faceted including but by far not restricted to the following: direct health risks by poorly understood effects of COVID-19 infection, overloaded capacities of healthcare units, restricted and slowed down care of patients with non-communicable disorders such as cancer, neurologic and cardiovascular pathologies, among others; social risks - restricted and broken social contacts, isolation, professional disruption, explosion of aggression in the society, violence in the familial environment; mental risks - loneliness, helplessness, defenceless, depressions; and economic risks - slowed down industrial productivity, broken delivery chains, unemployment, bankrupted SMEs, inflation, decreased capacity of the state to perform socially important programs and to support socio-economically weak subgroups in the population. Directly or indirectly, the above listed risks will get reflected in a healthcare occupation and workload which is a tremendous long-term challenge for the healthcare capacity and robustness. The article does not pretend to provide solutions for all kind of health risks. However, it aims to present the scientific evidence of great clinical utility for primary, secondary, and tertiary care to protect affected individuals in a cost-effective manner. To this end, due to pronounced antimicrobial, antioxidant, anti-inflammatory, and antiviral properties, naturally occurring plant substances are capable to protect affected individuals against COVID-19-associated life-
\end{abstract}

Dietrich Büsselberg

dib2015@qatar-med.cornell.edu

Olga Golubnitschaja

Olga.Golubnitschaja@ukbonn.de

Peter Kubatka

peter.kubatka@uniba.sk

Alena Liskova

liskova80@uniba.sk

Lenka Koklesova

koklesova5@uniba.sk

Marek Samec

marek.samec@uniba.sk

Kevin Zhai

kez4003@qatar-med.cornell.edu

Miroslava Šudomová

sudomova@post.cz

Sherif T.S. Hassan

sherif.hassan@seznam.cz

Erik Kudela

erik.kudela@uniba.sk
Kamil Biringer

kamil.biringer@uniba.sk

Frank A. Giordano

frank.giordano@ukbonn.de

1 Department of Obstetrics and Gynecology, Jessenius Faculty of Medicine, Comenius University in Bratislava, 03601 Martin, Slovakia

2 Weill Cornell Medicine-Qatar, Education City, Qatar Foundation, Doha 24144, Qatar

3 Museum of Literature in Moravia, Klášter 1, 66461, Rajhrad, Czech Republic

4 Department of Applied Ecology, Faculty of Environmental Sciences, Czech University of Life Sciences Prague, Kamýcká 129, 16500 Prague, Czech Republic

5 Department of Radiation Oncology, University Hospital Bonn, Rheinische Friedrich-Wilhelms-Universität, Bonn, Germany

6 Predictive, Preventive and Personalised (3P) Medicine, Department of Radiation Oncology, University Hospital Bonn, Rheinische Friedrich-Wilhelms-Universität Bonn, 53127 Bonn, Germany

7 Department of Medical Biology, Jessenius Faculty of Medicine, Comenius University in Bratislava, 03601 Martin, Slovakia 
threatening complications such as lung damage. Furthermore, they can be highly effective, if being applied to secondary and tertiary care of noncommunicable diseases under pandemic condition. Thus, the stratification of patients evaluating specific health conditions such as sleep quality, periodontitis, smoking, chronic inflammation and diseases, metabolic disorders and obesity, vascular dysfunction, and cancers would enable effective managemenet of COVID-19-associated complications in primary, secondary, and tertiary care in the context of predictive, preventive, and personalized medicine (3PM).

Keywords Phytochemicals · Phenolic compounds · Phenolic acids · Flavonoids · Coumarins · Stilbenoids · Inflammation · Immunity · Cytokine storm - Lung damage - ARDS - Predictive preventive personalized medicine (3PM/PPPM) . Anti-inflammation, Antibacterial · Antiviral, COVID-19 · Cancer, Chronic diseases · Risk assessment $\cdot$ Signaling pathways · Therapy efficacy $\cdot$ Disease management $\cdot$ Health economy $\cdot$ Health policy

\section{Introduction}

\section{Risks related to the COVID-19 pandemic conditions with consequences for healthcare}

The risks related to the COVID-19 are multifaceted including but by far not restricted to the following:

- Direct health risks by poorly understood effects of COVID-19 infection, overloaded capacities of healthcare units, restricted and slowed down care of patients with non-communicable disorders such as cancer, neurologic and cardio-vascular pathologies, amongst others;

- Social risks - restricted and broken social contacts, isolation, professional disruption, explosion of aggression in the society, violence in the familial environment;

- Mental risks-loneliness, helplessness, defenceless, depressions;

- Economic risks-slowed down industrial productivity, broken delivery chains, unemployment, bankrupted SMEs, inflation, decreased capacity of the state to perform socially important programs and to support socio-economically weak subgroups in the population.

Directly or indirectly, the above listed risks will get reflected in a healthcare occupation and workload that is a tremendous long-term challenge for the healthcare capacity and robustness. Indeed, in a long-term way a significant increase in the incidence of mental disorders can be expected as well as generally increased mortality of noncommunicable diseases, due to the late diagnoses and delayed treatments.

\section{What did we learn from the COVID-19 pandemic in healthcare?}

Enormous long-term socioeconomic burden caused by the COVID-19 pandemic is currently resulting in the global acknowledgment of prediction, prevention, and personalization in healthcare as an unavoidable approach to save lives and to protect societies in a cost-effective manner.

Due to limited care capacities that medical units possess under pandemic conditions, per evidence, chronically diseased patients demonstrate poorer live-quality and outcomes, and consequently increased mortality rates [1]. Overall management of severe chronic diseases such as cancer is currently more challenging than in general. In this condition, healthcare givers are prompted to consider pandemic-related risks additionally to conventional ones in the area. Personalized risk assessment is an essential pillar of predictive strategies and targeted prevention in cancer management [2].

Comorbidities significantly increase the risks of poor outcomes in COVID-19-infected individuals. In particular, inflammation-related pathologies such as cancer are relevant in a reciprocal manner. To this end, the severe COVID-19 course is characterized by hypercytokinemia, an exaggerated immune response, and excessive release of pro-inflammatory cytokine mediators, called "cytokine storm." Affected individuals, even with mild disease course, months after the infection exhibit diffuse multiorgan symptoms similar to those reported for children with Multisystem Inflammatory Syndrome [3]. Moreover, the study performed in the UK demonstrated $80 \%$ of COVID-19-infected patients were treated at intensive care units, and over $50 \%$ mortality was associated with bacterial superinfections and severe disease course [4]. Proposed pathomechanisms consider evident interactions between the viral particles and the host microbiota including the oral cavity, the respiratory and gastrointestinal tracts [5].

Expert recommendations consider:

- optimal oral hygiene crucial for improved individual outcomes and reduced morbidity under the COVID-19 pandemic condition,

- anti-inflammatory medication,

- dual anti-microbial and anti-viral therapeutic effects as particularly effective for tertiary care to avoid severe complications linked to COVID-19 [4, 6-8]. 


\section{Approaches mitigating individual health risks are highly requested under pandemic and post-pandemic conditions}

The article does not pretend to provide solutions for all kind of health risks. However, it aims to present the scientific evidence of great clinical utility for primary, secondary, and tertiary care to protect affected individuals in a cost-effective manner. To this end, due to below discussed antimicrobial, antioxidant, anti-inflammatory, and antiviral properties, naturally occurring plant substances are capable to function as anti-COVID-19 agents also protecting affected individuals against COVID-19-associated life-threatening complications such as lung damage. Furthermore, they can be highly effective, if being applied to secondary and tertiary care of noncommunicable diseases under pandemic condition. Thus, the stratification of patients evaluating specific health conditions such as sleep quality [9], periodontitis [10], smoking [11], chronic diseases or chronic inflammation $[12,13]$, metabolic disorders or obesity [14], vascular dysfunction [15, 16], or cancer [17] would enable effective managemenet of COVID-19-associated complications in primary, secondary, and tertiary care in the context of 3PM. Indeed, flavonoids are abundant compounds found in many plants that are synthesized in a response to microbial attacks and are therefore expected to possess antimicrobial and antiviral capacity [18]. Also, phenolics are potent anti-inflammatory agents [19]. Therefore, phenolics exert significant mitigating effects in tertiary cancer care associated with their potent anti-inflammatory, antimicrobial, and antiviral activities.

\section{Antiviral effects}

Plant phenolics are associated with a significant antiviral capacity [20-25]. Indeed, numerous phenolic compounds exert potent antiviral capacity against the coronavirus family including novel SARS-CoV-2 virus [18, 26-29]. In addition, specific viruses (hepatitis $\mathrm{B}$, hepatitis $\mathrm{C}$, human papillomavirus, and human oncogenic herpesviruses such as Epstein-Barr virus and Kaposi's sarcoma-associated herpesvirus) contribute to about $10-15 \%$ global burden of human cancers [30-32]. Therefore, the utilization of antiviral compounds, such as naturally occurring flavonoids or other phenolics, to eliminate or suppress viral infections may significantly improve cancer management [30, 33, 34].

\section{Anti-inflammatory effects}

High morbidity and mortality associated with COVID-19 are related to the release of pro-inflammatory cytokines and thrombogenic agents leading to the destruction of the lung. However, many patients who recovered from or had mild COVID-19 symptoms exhibit symptoms of multisystem inflammatory syndrome originally reported in children, and similar conditions are observed in adults [3]. To this end, phenolics are highly effective against inflammatory storm [19] and multisystem inflammatory symptoms [3, 35-38] and thus improving the overall outcomes of COVID-19 patients also in the context of potential tertiary cancer care. Indeed, the potent anti-inflammatory capacity of phenolics offers novel opportunities to improve overall cancer management [39].

\section{Antimicrobial protection}

Plant phenolics are well-known antibacterial agents while the proposed antibacterial mechanisms include the inhibition of nucleic acid synthesis, inhibition of cytoplasmic membrane function, inhibition of the attachment and biofilm formation, inhibition of the porin on the cell membrane, inhibition of energy metabolism, alteration of the membrane permeability, and attenuation of the pathogenicity [40-43]. Pathologic composition of the gut microbiome can lead to the accumulation of pro-inflammatory and pro-tumorigenic bacteria or depletion of protective bacteria and eventually leads to colorectal cancer risk. Nevertheless, phenolics, especially flavonoids, exert a potent capacity to modify the gut microbiome, inflammatory responses, and the risk of colorectal cancer [44-46]. Further, flavonoids demonstrate periodontic benefits demonstrated through anti-microbial and anti-inflammatory efficacy [47].

\section{COVID-19-associated lung injury}

Human-to-human transmission of SARS-CoV-2 is mediated mainly through droplets emitted by coughing and sneezing $[48,49]$. The specific adaptive immune response is essential to eliminate the virus and avoid its progression from the asymptomatic initial stage. However, impairment of the immune response allows the infection to propagate, leading to tissue damage and inflammation. Lung inflammation is considered a major cause of life-threatening respiratory events in severe cases of COVID-19 [49]. Acute lung injury (ALI) is associated with severe inflammatory reactions resulting in the deterioration of gas exchange while lung edema as one of ALI manifestations can eventually lead to acute respiratory distress syndrome (ARDS) [50]. COVID-19-associated ARDS primarily results from a deregulated host response, followed by damage of alveolar cells and lung fibrosis. Exaggerated release of pro-inflammatory cytokines (cytokine storm) and loss of $\mathrm{T}$ lymphocytes describes the most aggressive presentation [51].

ARDS is characterized by acute and diffuse inflammatory damage of the alveolar-capillary barrier related to increased vascular permeability and reduced lung size and compliance while these factors compromise gas exchange [52]. COVID- 
19 is an acute respiratory disease, and nearly one third of COVID-19 patients develop severe lung edema, dyspnea, hypoxemia, or ARDS and more than half of patients with ARDS die [50]. ARDS is histopathologically defined as diffuse alveolar damage (DAD) of the lung [52]. DAD progresses through stages - the early acute or exudative phase, the proliferative or organizing phase, and the fibrotic phase $[48,53]$. Autopsies of most SARS-CoV-2 patients revealed different stages of DAD with fibrin-rich hyaline membranes, a high frequency of macro- and microvascular thrombosis [54, 55], interstitial and intra-alveolar proteinaceous edema, and type II pneumocyte hyperplasia, all of which are consistent with the ARDS histopathologic background [56]. Despite primary SARS-CoV-2 infection, DAD can be promoted by secondary infections such as bronchopneumonia and aspergillosis [48]. The action of SARS-CoV-2 in lung cells and ARDSinduced deregulation of immune-coagulative pathways affect the extent of pulmonary involvement in severe COVID-19.

Moreover, autopsies confirmed pulmonary fibrosis as a common event in COVID-19 [54]. Therefore, mortality in COVID-19 is strongly related to DAD and associated immunothrombosis in pulmonary capillary networks and adjacent vessels. DAD, in turn, is linked to SARS-CoV-2 infection of pneumocytes and endothelial cells, dysfunction of the pulmonary vasculature and systemic endothelial tissue, and associated aberrant cytokine responses [57]. Besides typical $\mathrm{DAD}$, acute fibrinous and organizing pneumonia (AFOP) was reported in postmortem biopsies of COVID-19 patients [48]. In addition to ARDS-associated features of diffuse alveolar injury observed in ARDS, fibrin thrombosis is often observed in the small pulmonary vasculature of COVID-19 patients; therefore, microthrombic complications contribute to the progression of COVID-19 [58]. Indeed, microthrombi were found in autopsies of COVID-19 patients with fibrin deposition within the capillaries. Microthrombi were also found in patients with less pronounced DAD [48].

In conclusion, the pathogenesis of lung injury associated with COVID-19 is evident at the alveolar level and comprises epithelial, vascular, and fibrotic effects (Fig. 1).

\section{Inflammation and cytokine storm in COVID-19}

After the recognition of viral antigens, innate and adaptive immunity is activated resulting in the production of proinflammatory cytokines and chemokines. Although cytokine release is crucial for the defense against viral infection, aberrant immune responses can result in organ injury, especially in the elderly or comorbid patients. Therefore, immune activation can become so excessive that it causes uncontrolled systemic inflammatory responses, a process known as a cytokine storm. Such exaggerated immune response is demonstrated by the overproduction of proinflammatory cytokines and chemokines such as IL-6, IL- $1 \beta$, tumor necrosis factor-alpha (TNF- $\alpha$ ), GM-CSF, and IFN- $\gamma$, among others. The cytokine storm is associated with severe COVID-19 and unfavorable outcomes in hospitalized patients [19, 59, 60]. Moreover, plasma levels of IL- 6 , IL-8, and TNF- $\alpha$ peaked before death as demonstrated in autopsies of COVID-19 patients [59]. The cytokine storm can cause thrombotic events, ARDS, and multiple organ failure, while cytokine storm-induced damage predominantly in the lungs is considered a direct cause of death from acute COVID-19 [19].

Although specific molecular mechanisms are not fully understood, molecular mediators of inflammatory and immunologic pathways associated with COVID-19 pathogenesis and lung damage are detailed in Table 1.

\section{Phenolic phytochemicals and phenolic rich herbal medicine against coronavirus-associated lung injury}

Phenolic compounds represent the most pronounced plant secondary metabolites [35]. More than 8000 phenolic compound structures are currently known $[79,80]$. Phenolic compounds comprise a heterogenous group of phytochemicals with phenyl rings bearing one or more hydroxyl groups [81]. The most important dietary phenolic compounds include simple phenols, phenolic acids, flavonoids, stilbenes, coumarins, lignans, and tannins [79, 80]. Figure 2 summarizes the classification of phenolic compounds and their biological activities.

This review discusses selected phenolics that occur in plants most frequently and their impact on inflammatory and immunologic pathways deregulated by COVID-19 and in course of the associated lung injury. Phenolic acids are considered the main plant phenolic compounds [80, 82, 83]. Flavonoids represent the largest group of phenolic compounds and comprise more than 6000 compounds in dietary plants [20, 84-86]. A representative stilbene is a resveratrol that is found mainly in the skin of grapes and wine [79, 87]. Coumarins, which are found in plants such as sweet grass and vanilla grass, constitute another subclass of phenolics; coumarins are also metabolites of microorganisms such as Streptomyces and Aspergillus species [79]. Curcumin, the main natural polyphenol found in the rhizome of Curcuma longa, is also widely known for its biological activities [88-91]. In addition to isolated phenolic compounds, whole plants contain a mixture of various phytochemicals including phenolics in a large extent. The presence of various phytochemicals within plants is considered to contribute to more pronounced pharmacological activity due to additive and synergistic effects $[92,93]$. Plants of traditional medicine rich in phenolic phytochemicals represent sources of various bioactive compounds [19, 29, 94]. Despite significant 


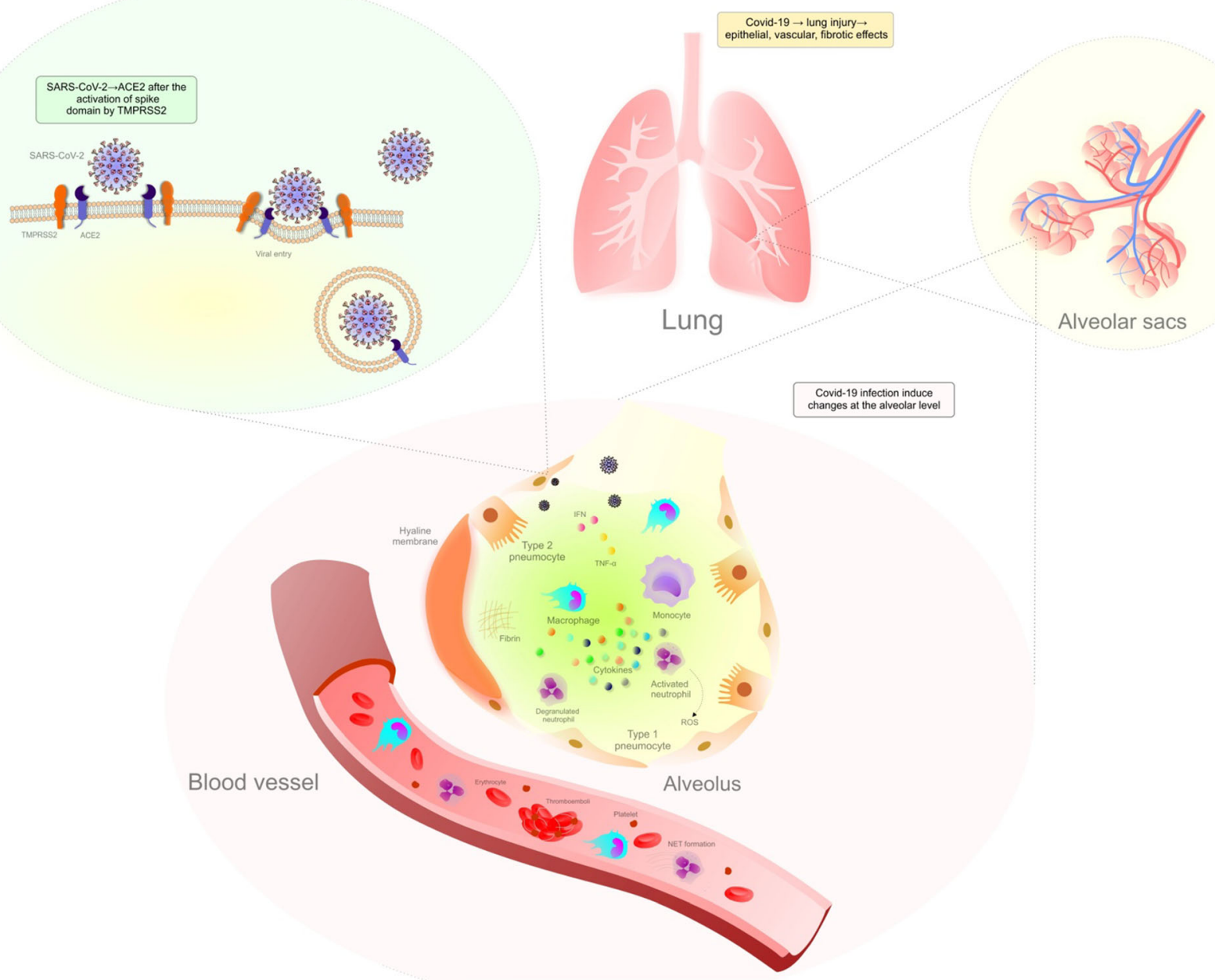

Fig. 1 COVID-19: lung injury comprises epithelial, vascular, and fibrotic effects. Abbreviations: ACE2, angiotensin-converting enzyme 2; AFOP, acute fibrinous and organizing pneumonia; DAD, diffuse alveolar damage; IFN, interferon; NET, neutrophil extracellular traps; ROS, reactive oxygen species; TMPRSS2, transmembrane serine protease 2; TNF- $\alpha$, tumor-necrosis factor-alpha; $\rightarrow$, leading to/resulting in. Explanatory notes: SARS-CoV-2 enters the cell through the ACE2 receptor after the activation of the spike domain by TMPRSS2 $[48,49]$. Lung injury by COVID-19 has epithelial, vascular, and fibrotic effects [48]. Pulmonary alveoli are lined with type I and II epithelial cells surrounded by capillaries to promote gas exchange. SARS-CoV-2-induced alveolar damage $\rightarrow$ build-up of debris and fluid inside the alveolus (affects gas exchange associated with pro-inflammatory responses, increases vascular permeability, and induces fibrosis with collagen deposition and thrombosis) [48]. SARS-CoV-2 directly infects alveolar type I and II epithelial cells $\rightarrow$ loss of epithelial layer and occurrence of DAD (stimulated by the innate immune response). Alveolar capillary damage $\rightarrow$ fluid accumulation (capillary leak and intra-alveolar hemorrhage). DAD: exudative $\rightarrow$ hyaline membranes of serum proteins and condensed fibrin [48, 53], interstitial and alveolar edema, capillary congestion and microthrombi, inflammatory cell infiltrates, scattered fibroblasts, thickening of the alveolar septa, denudation of the alveolar epithelium, and type II hyperplasia within a few days of infection; organizing $\rightarrow$ proliferation of fibroblasts in septa and alveolar spaces to begin tissue repair through the organization of edema, the disappearance of hyaline membranes, atypia of pneumocytes, thromboembolic in capillaries and pulmonary vessels; fibrotic $\rightarrow$ stage in approximately 3 to 4 weeks [48]. Intra-alveolar hemorrhage is also observed in COVID-19 patients. The alveolar space can be infiltrated by inflammatory cells, neutrophils, megakaryocytes, macrophages, and other components that damage its function [48]. Monocytes recruited into the alveolar space secrete pro-inflammatory cytokines and induce the apoptosis of pneumocytes through the release of IFN through a pathway dependent on TNF- $\alpha$ activating cell death receptors. Macrophages release chemokines and other cytokines $\rightarrow$ increased permeability and the recruitment of neutrophils. Excessive neutrophil degranulation leads to damage and breakage of the alveolarcapillary barrier [52]. AFOP $\rightarrow$ formation of fibrin balls in the alveolar space blocks airflow into the alveoli, formation of hyaline membrane, and thickening of the septa for gas exchange and can also contribute to fibrosis. Loss of type I and II epithelial cells contributes to the flooding of alveoli with blood, edema, or cellular debris due to lost or impaired ion channels; this further degrades epithelial cells and the surfactant layer (reduced area of gas exchange). In response, the surrounding alveoli increase in volume, and the forces on the alveolar walls increase leading to increased stress surrounding the foci of injury, leading to further damage. With the progress of lung injury, more alveoli are damaged which leads to decreased lung compliance. Indeed, alveolar collapse, surfactant dysfunction, intra-alveolar edema, lung inflammation, and focal fibrotic remodeling are all lung stress concentrators that cause further injury progression. Microthrombi were found in autopsies of COVID-19 patients with observed deposition of fibrin within the capillaries. Neutrophils also contribute to capillary damage through NETs, which promote vascular occlusion due to the high neutrophil content of clots in capillaries of the alveolar septa. Platelet, fibrinogen, and neutrophil microthrombi and NET formation associated with immunothrombosis were observed in COVID-19 patients' lungs when compared with nonCOVID-19 controls. Neutrophils generate excessive ROS, which induces further lung damage [48] 
Table 1 Molecular mediators of inflammatory and immunologic pathways associated with COVID-19 pathogenesis and lung damage

Molecular mediators Mechanisms Reference

NF-kB Modulation of immune cell functions and cytokine expression in response to pathogenic stimuli. Many proinflammatory factors induce NF- $\mathrm{kB}$ signaling. NF- $\mathrm{kB}$ potentiates ROS production (leading to apoptosis in various tissues in diseases and viral infections).

MMPs

COVID-19 activation of NF- $\mathrm{kB}$ leads to the production of IL-1, IL-2, IL-6, IL-12, TNF- $\alpha$, and GM-CSF.

MMP2 and MMP8 are upregulated in COVID-19-affected lung tissue.

MMP9 released from neutrophils in ALI promotes inflammation and degradation of the alveolar-capillary barrier, thus stimulating the migration of inflammatory cells and lung destruction. MMP-9 has the potential as an early indicator of respiratory failure in COVID-19.

JAK/STAT The SARS-CoV-2 infection triggers inflammation via the JAK/STAT pathway, resulting in the recruited pneumocytes, endothelial cells, monocytes, lymphocytes, macrophages, natural killer cells, and dendritic cells progressing towards cytokine storm $\rightarrow$ production of inflammatory markers and mediation of immune responses via $B$ cell and $T$ cell differentiation.

Advanced stage (critically ill COVID-19 patients) $\rightarrow$ cytokine storm (inflammatory mediators using the JAK/STAT signaling pathway such as IL-6, IFN- $\gamma$, result in an influx of macrophages and neutrophils damaging the lung tissue)

p38 MAPK Disproportionately upregulated p38 MAPK in SARS-CoV-2 can be a result of infection due to loss of ACE2 activity upon viral entry and by direct viral activation of 338 MAPK.

The crucial role of 38 MAPK in the release of proinflammatory cytokines and acute lung injury.

p38 MAPK activation may also promote viral entry via ACE2

ROS

Excessive ROS causes RBC membrane peroxidation that perpetuates neutrophil activation. Exaggerated oxidative [68] stress might be responsible for alveolar damage, thrombosis, and RBC deregulation in COVID-19.

COX and PGs Pro-inflammatory action in COVID-19, PGE2 inhibition can promote the host immune response.

(PGE-2)

Ang-2, ICAM-1 Markers of endothelial and/or alveolar epithelial injuries (elevated in COVID-19-related ARDS non-survivors when compared with survivors).

MIP $1-\alpha$

Often increased in COVID-19 patients.

NO, iNOS

The association between disruption of NO physiology and ARDS development in COVID-19.

NO produced by eNOS is compromised (induces alteration in lung parenchyma and coagulopathy), but NO produced by iNOS increases with an effort to fight the virus.

Exaggerated NO can generate pro-inflammatory effects.

TLRs (a subfamily of Recognize SARS-CoV-2 in the extracellular milieu or endosomes and mediate the inflammatory signaling that PRR) leads to proinflammatory cytokine production.

TLR4 is highly expressed during lung injury.

STAT3, PAI-1 Positive feedback loop between STAT3 and PAI-1 - association with COVID-19; upregulated PAI-1 leads to intravascular thrombi and overproduced PAI-1 binds to TLR4 on macrophages and induces the release of pro-inflammatory cytokines and chemokines. The subsequent activation of innate immune cells within the infected lung leads to the destruction of lung architecture and subsequent hypoxic environment further stimulates PAI-1 production. In addition, acute lung injury activated EGFR and phosphorylation of STAT3. Indeed, DAD also increases PAI-1 levels.

BRD4 BRD4 is an epigenetic reader of acetylated lysines that plays an important role in epithelial-driven and $\mathrm{NF}-\mathrm{kB}$-dependent innate inflammation during viral infection.

Nrf2 The association between respiratory viral infections, inflammation, and oxidative stress of the epithelium lining cells $\rightarrow$ activation of Nrf2 to protect cells from oxidative damage and inflammation.

The severity of COVID-19 is related to preexisting conditions (impaired immune responses, obesity, or age, which are associated with decreased Nrf2 levels).

Nrf2 activation reduces inflammation, restores the cellular redox balance, and facilitates tissue repair.

$\operatorname{PPAR} \gamma$

Dysfunction in M1 monocytes/macrophages in the innate immune response is characterized by the repression of $\operatorname{PPAR} \gamma$; this is associated with the cytokine storm induced by inflammatory monocytes/macrophages in the SARS-CoV-2-infected lung.

$[19,51,76$

Abbreviations: ACE2, angiotensin-converting enzyme 2; ALI, acute lung injury; Ang-2, angiopoietin-2; BRD4, bromodomain-containing protein 4; COX, cyclooxygenase; eNOS, endothelial nitric oxide synthase; GM-CSF, granulocyte-macrophage colony-stimulating factor; ICAM-1, intercellular adhesion molecule-1; IFN- $\gamma$, interferon-gamma; IL, interleukin; iNOS, inducible nitric oxide synthase; JAK/STAT, Janus kinase/signal transducers and activators of transcription; MIP 1- $\alpha$, Macrophage inflammatory protein 1- $\alpha$; MMP, Matrix metalloproteinase; NF- $\mathrm{B}$, nuclear factor-kappa B; NO, nitric oxide; Nrf2, nuclear factor erythroid-derived 2-related factor 2; p38 MAPK, p38 mitogen-activated protein kinases; PAI-1, plasminogen activator inhibitor-1; PAI-1, plasminogen activator inhibitor-1; PGE2, prostaglandin E2; PGs, prostaglandins; PPAR $\gamma$, peroxisome proliferator-activated receptor; PRR, pattern recognition receptors; RBC, red blood cell; ROS, reactive oxygen species; TLRs, Toll-like receptors

pharmacological activities, the disadvantage of the usage of naturally occurring phytochemicals in vivo is their low water solubility, low gastrointestinal absorption, poor stability in body fluids, rapid metabolism, and rapid clearance [95]. 


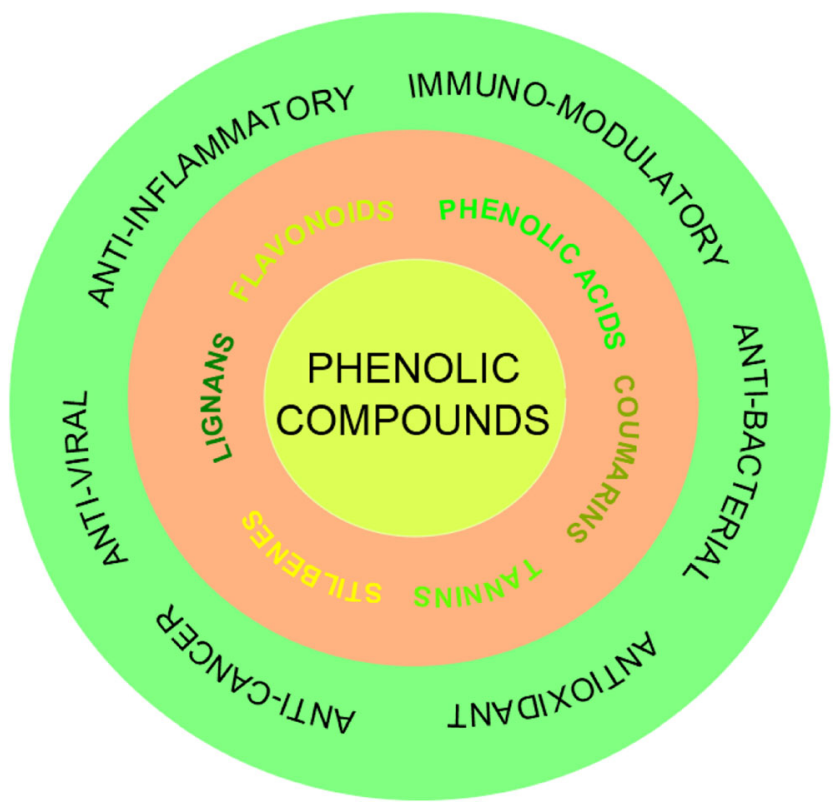

Fig. 2 Classification and biological activities of plant phenolic compounds

Nevertheless, the ongoing research is intensively identifying novel approaches to increase the bioavailability or promote the effectiveness of targeted delivery of phenolic compounds through the introduction of specific strategies such as nanocarrier systems [19, 96-99]. After all, due to the numerous biological effects including but not limited to antioxidant, anticancer, anti-inflammatory, immunomodulatory activities [83, 84, 93, 100-103], and their important role in managing lung injury by multiple mechanisms [104], phenolics are suggested to possess significant capacity against COVID-19.

\section{Phenolic acids}

Phenolic acids are found in fruit seeds and skin and vegetable leaves [80]. Phenolic acids include hydroxybenzoic acids (HBAs) and hydroxycinnamic acids (HCAs), which are derived from benzoic and cinnamic acid, respectively [82, 83]. HBAs include gallic acid, salicylic acid, ellagic acid, and protocatechuic acid, while major HCAs include p-coumaric acid, caffeic acid, and ferulic acid. Phenolic acids represent pharmacologically active phytochemicals that exert antioxidant, anticancer, anti-inflammatory, or immunomodulatory efficacy [36]. Ellagic acid and gallic acid both demonstrate anti-inflammatory effects through the inhibition of lipopolysaccharide (LPS)-induced NO, PGE-2, and IL-6 production in vitro [105]. LPS-induced inflammation is accepted as a classic inflammatory model [106]. Also, gallic acid inhibits the inflammatory response in macrophages through the blockage of TLR4/NF-KB induced by LPS [107]. In addition, gallic acid has been recently observed to effectively modulate pulmonary inflammation associated with chronic obstructive pulmonary disease (COPD), an inflammatory lung disease, in elastase (ET) and cigarette smoke (CS)-induced mice model demonstrated through the attenuation of pro-inflammatory cytokines (IL-6, TNF- $\alpha$, IL-1 $\beta$ ) and to downregulate gene expression of elevated expression of pro-inflammatory factors such as TNF- $\alpha$, IL-1 $\beta$, MIP-2, KC, and GCSF in lungs [108]. Moreover, caffeic acid derivatives show potential for the treatment of ALI demonstrated in a model of mouse primary peritoneal macrophages activated by LPS [109]. Similarly, protocatechuic acid exerts protective effects against LPSinduced ALI in mice and reduces TNF- $\alpha$ and IL- $1 \beta$ by suppressing p38MAPK and NF-KB [110]. Based on welldescribed anti-inflammatory and immunomodulatory activities, phenolic acids could represent an abundant source of highly effective anti-COVID-19-lung damage agents [111]. Molecular docking, a computational technique to estimate the affinity of association between two molecules (e.g., protein-ligand or protein-protein), [112] is an effective tool for in silico screening in drug discovery [113]. To this end, molecular docking simulations revealed that specific gallic acid derivatives inhibit five nonstructural SARS-CoV-2 proteins [111]. Similarly, the confirmed capacity of caffeic acid derivatives as SARS-CoV-2 inhibitors can support the development of lead structures in COVID-19 therapy or prophylaxis [114]. Moreover, molecular docking has been recently utilized to assess specific biologically active compounds of medicinal plants (such as gallic acid, quercetin, naringin, or capsaicin) in the inhibition of SARS-CoV-2 infection [112]. Lastly, a preliminary report by Tito et al. suggests that a pomegranate peel extract rich in polyphenols, such as gallic acid, ellagic acid, glycosylated derivatives, anthocyanins, and ellagitannins, is a promising source of novel agents against COVID-19 [115].

In conclusion, the biological activities of phenolic acids predetermine them as potentially beneficial compounds against COVID-19-associated complications.

\section{Flavonoids}

Flavonoids represent a group of polyphenolic phytochemicals with potent pharmacological activities. Main flavonoid classes include flavonols, flavones, flavanones, flavanols (the monomer form catechins), isoflavones, flavanonols, and anthocyanidins [20,84]. Despite antioxidant or anticancer capacity $[19,84,102]$, flavonoids are also effective antiinflammatory and immunomodulatory agents [113]. Various flavonoids (such as luteolin, apigenin, quercetin, rutin, naringin, and naringenin) exert anti-inflammatory effects through the modulation of inflammatory mediators such as TNF- $\alpha$, IL- $1 \beta$, IL- 6 , IL- 8 , and IFN- $\gamma$ [116-120]. Other plant-derived flavonoids (flavonoid derivatives and flavonoid glycosides) such as tanshinone IIA, hyperoside, kaempferol, astragalin, isorhamnetin, isovitexin, rhamnazin, morin, 
troxerutin, engeletin, silibinin, sakuranetin, and $2^{\prime} O$ galloylhyperin were reported with the ability to manage acute lung injury by multiple mechanisms of action [104]. Moreover, flavonoids can stimulate the switch of macrophages from pro-inflammatory to anti-inflammatory phenotype $[19,121]$ and also regulate functions of immunity through the enhancement of the activity of NK cells and cytotoxic $\mathrm{T}$ lymphocytes and also through the macrophage functions via modulation of lysosomal activity and the release of NO [19, 120]. Besides, flavonoids can attenuate lung injury as demonstrated by the capacity of baicalein, an active compound of Scutellaria baicalensis Georgi belonging to the flavone subclass of flavonoids [84, 102], to reduce histological damage and lung cell apoptosis and inhibit IL-6, IL-1, and TNF- $\alpha$ in a rat model of lung injury induced by myocardial ischemia and reperfusion [122]. Similarly, luteolin attenuated sepsis-induced ALI in mice by suppressing ICAM-1, NF-kB, oxidative stress, and the iNOS pathway [123], and protected against mercuric chloride-induced lung injury in mice by preventing NF-kB activation and activating Akt/Nrf2 [124]. In addition, hesperidin alleviated influenza A-induced lung injury in rats through the inhibition of cytokine production in pulmonary microvascular endothelial cells by suppressing MAPK signaling [125]. As discussed above, the exaggerated immune response caused by SARS-CoV-2 infection can result in a cytokine storm, thrombotic events, ARDS, and multiple organ failure. Cytokine storm-induced lung damage is a direct cause of death from acute COVID-19 [19]. Therefore, the anti-inflammatory and immunomodulatory activities of flavonoids utilizable in COVID-19 are currently largely investigated. The flavonoid-based phytomedicine caflanone binds with high affinity to the spike protein, helicase, and protease sites on the ACE2 receptor used by SARS-CoV-2 to infect cells; moreover, caflanone inhibits the production of cytokines including IL-1 $\beta$, IL-6, IL-8, Mip- $1 \alpha$, and TNF- $\alpha$ in vitro [113]. In addition, the pharmacological activity of citrus fruitsparticularly their flavonoid component hesperidin - has been recently discussed in the context of COVID-19 [126]. Indeed, hesperidin exerts anti-inflammatory effects demonstrated by decreasing IL-33 and TNF- $\alpha$ in mice co-treated with hesperidin and LPS [127]. Apart from their anti-inflammatory and immunomodulatory effects, the effects of flavonoids on lung tissue are also currently evaluated in COVID-19 research. Baicalein exerts a potent pharmacological capacity including antiviral efficacy. Preclinical trials demonstrate the capacity of baicalein to inhibit SARS-CoV-2-induced cell damage in Vero E6 cells. Baicalein also inhibits viral replication and relieves lung tissue lesions in hACE2 transgenic mice infected with SARS-CoV-2. Moreover, baicalein administration improves respiratory function, inhibits inflammatory cell infiltration in the lung, and decreases serum levels of IL-1 $\beta$ and TNF- $\alpha$ in mice with LPS-induced acute lung injury [128]. Another bioactive flavonoid from Scutellaria baicalensis
Georgi named baicalin has recently been shown to inhibit the replication of SARS-CoV-2 evaluated in Vero and human Calu-3 cells with $\mathrm{EC}_{50}$ values of 9.0 and $8.0 \mu \mathrm{M}$, respectively. The underlying mechanism was revealed via inhibiting SARS-CoV-2 RNA-Dependent-RNA Polymerase [129]. Another mechanism of action was also disclosed in an in vitro assay via suppressing the activity of SARS-CoV-2 3CLpro $\left(\mathrm{IC}_{50}=6.41 \mu \mathrm{M}\right)$, a protease enzyme required for SARS-CoV-2 replication [130]. Furthermore, baicalin in multiple in vivo experiments was noticed to relieve lung impairment as revealed by attenuated myeloperoxidase (MPO) activity, lung edema, and lung histopathologic changes in acute lung injury models caused by various stimuli including some viruses from coronavirus family [131-133]. Baicalin was also found to decrease pulmonary inflammation by downregulating the expression of pro-inflammatory cytokines TNF- $\alpha$, IL-1 $\beta$, IL-6, IL-8, IL-18, IL-23, and matrix metallopeptidase 9 (MMP9) [131]. Moreover, lung oxidative injury was detected to be suppressed by baicalin through decreasing malondialdehyde (MDA) [134]. In an animal study, baicalin $(50 \mathrm{mg} / \mathrm{kg})$ was proved to significantly improve pulmonary function, inflammatory cell infiltration, and cytokine expression (TNF- $\alpha$, IL-6, and MMP9) [135]. Considering the above-mentioned animal studies, we can conclude that baicalin has a promising application in the treatment of acute lung injury or lung damage that are associated with SARSCoV-2 post infection.

The catechin (-)-epigallocatechin-3-gallate (EGCG), the main flavonoid compound of green tea, has recently been documented in a comprehensive review article that demonstrated its potential protective effect against SARS-CoV-2 infection via multiple mechanisms of action that target viral or host cell proteins evaluated in various preclinical experiments. The protective effects of EGCG are related to preventing cytokine storm-associated acute lung injury/acute respiratory distress syndrome, thrombosis by inhibiting tissue factors and activating platelets, sepsis by inactivating redoxsensitive high mobility group box 1 (HMGB1), and lung fibrosis via increasing Nrf2 and hindering NF- $\mathrm{KB}$ activation [136].

Based on the discussed anti-inflammatory, immunomodulatory, and lung-protective activities of flavonoids and supported by current studies focusing on the models of SARSCoV-2-induced infection, flavonoids could represent a source of potential phytochemicals in the development of prophylactics or therapeutics against COVID-19.

\section{Stilbenoids}

Stilbenoids are phenolic compounds found in plants, berries, and nuts [137] that share a stilbene backbone structure and differ in the nature and position of their substituents. Stilbenoids are phytoalexins, antimicrobial compounds 
produced in plants de novo to protect them against infections or toxins; this class of compounds includes gnetol, piceatannol, and resveratrol [138]. Stilbenoids are wellknown anti-inflammatory agents that target iNOS, COX, leukotrienes, NF-kB, TNF- $\alpha$, interleukins [139], or PI3K/Akt [137]. Moreover, stilbenoids exert significant antioxidant and immunomodulatory effects $[139,140]$ and are potent anti-viral compounds [141]. Resveratrol inhibits the replication of various viruses (dengue, Zika, influenza), including MERS-CoV [142]. Moreover, resveratrol demonstrated a capacity to reduce ALI and inflammation in a murine LPSinduced sepsis model through Sirtuin 1 (Sirt1) regulation, an important regulator of inflammation [143]. Similarly, pretreatment with 3,5,4'-tri- $O$-acetylresveratrol decreased ALI induced by seawater inhalation through interfering with NF- $\mathrm{KB}$ and iNOS pathways followed by decreased NO, TNF- $\alpha$, and IL-1 $\beta$ [144]. Therefore, stilbenoids may be effective against SARS-CoV-2. Resveratrol shows a capacity to inhibit SARSCoV-2 infection in Vero cells infected with SARS-CoV-2 suggesting its potential role as a novel COVID-19 therapeutic [142]. As discussed above, ARDS is a severe complication of COVID-19 patients that results in almost $40 \%$ mortality. However, resveratrol has been suggested to attenuate Staphylococcal enterotoxin B (SEB)-induced ARDS. Therefore, Alghetaa et al. have evaluated the effects of resveratrol on the gut and lung microbiota in $\mathrm{C} 3 \mathrm{H} / \mathrm{HeJ}$ mice with SEB-induced inflammatory cytokines, ARDS, and $100 \%$ mortality. Resveratrol demonstrates the capacity to attenuate ARDS at least partially by altering the gut and lung microbiota, specifically through the induction of beneficial bacteria such as L. reuteri [145]. Furthermore, pterostilbene is an additional dimethyl ether and a more stable analog of resveratrol that pharmacologically resembles other stilbenes [146, 147]. Based on a preliminary report by Ellen et al., resveratrol and pterostilbene significantly inhibit SARS-CoV-2 infection in primary human bronchial epithelial cells cultured under ALI conditions [147]. Kobophenol A, a bioactive oligomeric stilbenoid isolated from the Caragana genus, has effectively inhibited the infectivity of SARS-CoV-2 (in vitro) with an $\mathrm{EC}_{50}$ of $71.6 \mu \mathrm{M}$. The mechanism was unveiled by blocking the interaction between the ACE2 receptor and S1-RBD in vitro with an $\mathrm{IC}_{50}$ of $1.81 \mu \mathrm{M}$. The results were also confirmed by molecular docking and molecular dynamic simulation studies [148]. Besides, Kobophenol A has previously been described to possess anti-inflammatory and antioxidant activities [149] and therefore might prevent lung injury linked with SARS-CoV-2 infection as well as other inflammatory diseases and cancer.

In conclusion, the potential effects of stilbenoids supported by already proven anti-inflammatory, immunomodulatory, and anti-viral efficacy and initial results from SARS-CoV-2 research require further evaluation under COVID-19 conditions.

\section{Coumarins}

Coumarins are natural compounds found in plants, fungi, and bacteria [150]. Coumarins shows potent anticancer, antibacterial, antifungal, antioxidant, anti-inflammatory, antithrombotic, and antiviral activities $[151,152]$. Significant antiinflammatory effects of sesquiterpene coumarins from Ferula fukanensis was demonstrated through the inhibition of NO, iNOS, IL-6, and TNF $\alpha$ gene expression in murine macrophage-like cell line RAW264.7 activated by LPS and recombinant mouse IFN- $\gamma$ [153]. Therefore, coumarins could exert also a potential efficacy against COVID-19. Coumarin derivatives reveal effectiveness as potential inhibitors of the enzymes essential for SARS-CoV-2 viability in silico [154]. Another study aiming to identify selective antiviral agents for the management of COVID-19 pathologies has demonstrated a capacity of coumarin-24 to be effectively used against COVID-19 infection [155]. Most importantly, in silico screening of natural products isolated from Mexican Herbal Medicines reveals the ability of coumarin cichoriin to reach an acceptable level in plasma and high lung levels, while these results suggest its potential as a novel therapeutic tool against COVID-19 [156]. Due to the significant potential of coumarins against SARS-CoV-2, Chidambaram et al. have recently evaluated the possibility of synthesis of novel coumarin analogues to identify drugs against COVID-19 [157].

Therefore, and similar to other members of plant phenolic compounds, coumarins could also represent a rich and effective source of bioactive compounds targeting infection induced by SARS-CoV-2.

\section{Traditional herbal medicine rich in phenolics protecting against SARS-CoV-2-induced lung damage}

Notably, traditional herbal medicine such as traditional Chinese medicine, with its main active constituents including to a large extent phenolic compounds, could also exert significant activity against lung damage and associated inflammatory and immunomodulatory deregulations observed in COVID-19 [156, 158]. Immune dysfunction is essential for COVID-19 progression; therefore, the administration of phytochemicals or herbal medicines containing certain compounds with antimicrobial, antiviral, anti-inflammatory, and immune-modulatory effects have great potential as effective prophylactic and therapeutic agents against SARS-CoV-2 [159]. Indeed, the blockage of the cytokine storm can represent an effective tool against SARS-CoV-2 [159]. Chinese herbal medicine Arenaria kansuensis is known for its antiviral activity has been long used to treat pulmonary disease is suggested to exert beneficial effects also against COVID-19. Therefore, Cui et al. have recently evaluated the protective capacity of Arenaria kansuensis ethanol extract (AE) on pulmonary fibrosis in paraquat (PQ)-induced pulmonary fibrosis 
animal models. The study results reveal improved destruction degree of lung tissue structure with increasing AE dosage, reduced collagen deposition in lung interstitium, and reduced degree of inflammatory infiltration and inflammatory cytokines; indeed, the protective effect of AE on pulmonary fibrosis was partly due to activation of Nrf2 pathway and the inhibition of NF-kB/TGF- $\beta 1 / \mathrm{Smad} 2 / 3$ pathway [160]. Another herbal therapy, Shufeng Jiedu has been also suggested as a promising drug for the treatment of COVID-19 demonstrated in the HCoV-229E mice model of lung index. Shufeng Jiedu decreased the viral load in the lung, attenuated cytokine release, and increased T- and B-lymphocytes. The authors conclude that Shufeng Jiedu significantly downregulates the inflammatory factors IL-6, IL-10, TNF- $\alpha$, and IFN- $\gamma$ in the lung and increases CD4+ and CD8+ cells in the blood compared to the model group. In addition, ShufengJiedu can reduce NF- $\mathrm{KB}$ activity. Moreover, ShufengJiedu constituents quercetin, wogonin, and polydatin bind directly to the main protease (Mpro) of SARS-CoV-2. Therefore, ShufengJiedu is a promising drug against COVID-19; however, further validation in clinical trials is needed [161].

Moreover, a case report recently reported a 61-yearold female COVID-19 patient whose lung inflammatory exudate, pulmonary fibrosis, and quality of life significantly improved after oral treatment with traditional Chinese medicine decoction alone [162]. Plant extracts are complex multicomponent mixtures. Indeed, fingerprinting and chemical profiling are essential for the acceptance and quality control of traditional herbal medicines. Divya-Swasari-Vati (DSV) is a calciumcontaining herbal medicine with a long history of use against respiratory infections. DSV is also used to control COVID-19-associated respiratory symptoms [159]. DSV exerts its pharmacological activity against SARSCoV-2-induced inflammation in a humanized zebrafish model through the amelioration of the inflammation induced by SARS-CoV-2 spike protein demonstrated by the blockage of pro-inflammatory IL- 6 and TNF $\alpha$ cytokine surge [163]. Indeed, high-performance liquid chromatography-diode array detection (HPLC-DAD) has been recently used to estimate the levels of several phytochemicals, including but not restricted to phenolics (gallic acid, protocatechuic acid, ellagic acid, coumarin, cinnamic acid, glycyrrhizin, eugenol, 6-gingerol, piperine, methyl gallate, and glabridin), in five batches of DSV [159].

Traditional herbal medicine, which is composed of specific plants containing a mixture of various phytochemicals, has a long history of its applicability to maintaining human health. Therefore, such mixtures of various biological active phytochemicals are suggested to be significantly effective against COVID-19 while this efficacy has been at least partly observed also in a clinical setting.

\section{Extended polyphenolic compounds}

Curcumin (diferuloylmethane) is a yellow pigment and natural polyphenol present in the turmeric spice (Curcuma longa) $[95,164]$. Curcumin exerts various pharmacological activities, including antioxidant, anticancer, anti-inflammatory, and anti-infective. Curcumin affects various signaling molecules associated with the inflammatory processes, such as TNF- $\alpha$, IL- $1 \beta$, NF-kB, COX-2, and iNOS $[165,166]$. Curcumin was observed to regulate the differentiation of naïve $\mathrm{CD} 4+\mathrm{T}$ cells and activate IL-10 immune modulation against acute lung injury in mice and thus alleviated lung injury and suppressed uncontrolled inflammation [167]. The evaluation of the effects of curcumin on ALI revealed suppressive activity on EGFR and proliferative protein Ki67 in ALI and lung fibrosis in vitro and in vivo [168].

Similarly, direct pulmonary delivery of solubilized curcumin reduced injury, inflammation, and mortality in a mouse model of lethal pneumonia [169]. Based on the above discussed biological activities, curcumin is suggested as a potential option against COVID-19 due to its capacity to affect not only the viral entrance, encapsulation, and replication but also various signaling cascades of inflammation [96]. EGYVIR is an immunomodulatory herbal extract composed of black pepper extract and curcumin extract. EGYVIR has revealed effectiveness against SARS-CoV-2 in vitro through modulating NF-k $\beta / \mathrm{TNF} \alpha / \mathrm{IL}-6$ during the infection process. Also, EGYVIR antagonizes NF- $\mathrm{kB}$ pathway in silico and in vitro and has the potential to hinder the release of IL-6 and TNF $\alpha$, thus decreasing the production of elements associated with the cytokine storm [170]. Moreover, Noor et al. recently evaluated the immunomodulatory and anti-cytokine therapeutic potential of curcumin and its derivatives targeted against COVID-19 immunological human host receptors, i.e., ACE2, IL-1 $\beta$, IL-6, TNF- $\alpha$, and protease-activated receptor (PAR)-1 to prevent viral infection and control overproduction of early clinical responses. Eventually, computational modeling demonstrates the immunomodulatory and anticytokine therapeutic potential of hydrazinocurcumin against COVID19; however, further in vivo investigations are needed to confirm hydrazinocurcumin as a COVID-19 drug [171]. Despite significant pharmacological activities, the disadvantage of the usage of natural phytochemicals such as curcumin includes its low bioavailability and rapid metabolism [95]. The study conducted on COVID-19 patients reveals a significant decrease in Th17 cells, Th17 cell-related factors, and levels of Th17 cellrelated cytokines in mild and severe COVID-19 patients treated by nano-curcumin compared to the placebo group thus demonstrating the potential of curcumin to improve COVID19 patient's inflammatory condition [172]. Moreover, an evaluation of nano-curcumin oral formulation effectiveness in hospitalized patients with mild-to-moderate COVID-19 has 
Table 2 Potential actions of specific plant phenolics against lung damage induced by SARS-CoV-2

\begin{tabular}{|c|c|c|c|c|}
\hline Phenolic compound & Study details & Mechanisms & Effects & Reference \\
\hline \multicolumn{5}{|l|}{ Phenolic acids } \\
\hline Ellagic acid and gallic acid & RAW264.7 cells & $\begin{array}{l}\text { Inhibition of LPS-induced NO, } \\
\text { PGE-2, IL-6 }\end{array}$ & Anti-inflammatory & {$[105]$} \\
\hline Gallic acid & RAW264.7 macrophages & $\begin{array}{l}\text { Blockage of TLR } 4 / N F-k B \text { induced } \\
\text { by LPS }\end{array}$ & Anti-inflammatory & {$[107]$} \\
\hline Gallic acid & $\begin{array}{l}\text { ET- and CS-induced murine } \\
\text { model }\end{array}$ & $\begin{array}{l}\text { ET: decrease in IL- } 6 \text {, TNF- } \alpha \text {, IL- } 1 \beta \\
\text { CS: decrease in TNF- } \alpha \text { and the } \\
\text { inflammatory chemokines MIP- } 2 \\
\text { and KC. }\end{array}$ & $\begin{array}{l}\text { Modulation of COPD-associated } \\
\text { pulmonary inflammation }\end{array}$ & {$[108]$} \\
\hline Caffeic acid derivatives & $\begin{array}{l}\text { Murine primary peritoneal } \\
\text { macrophages activated by } \\
\text { LPS }\end{array}$ & $\begin{array}{l}\text { Prevented formation of } \\
\text { LPS/MD2/TLR4 }\end{array}$ & $\begin{array}{l}\text { Anti-inflammatory (potential for } \\
\text { ALI treatment) }\end{array}$ & [109] \\
\hline Protocatechuic acid & $\begin{array}{l}\text { LPS-induced ALI in a } \\
\text { murine model }\end{array}$ & $\begin{array}{l}\text { Reduced TNF- } \alpha \text { and IL-1 } \beta \\
\text { mediated through suppressed } \\
\text { p38MAPK and NF- } \mathrm{BB}\end{array}$ & Protective effects against ALI & {$[110]$} \\
\hline Gallic acid derivatives & Molecular docking & $\begin{array}{l}\text { Inhibitory effects against five } \\
\text { non-structural SARS-CoV-2 } \\
\text { proteins }\end{array}$ & Potential against SARS-CoV-2 & [111] \\
\hline $\begin{array}{l}\text { Bioactive compounds of } \\
\text { medicinal plants }\end{array}$ & Molecular docking & \multicolumn{2}{|c|}{ Potential inhibition of SARS-CoV-2 infection } & [112] \\
\hline $\begin{array}{l}\text { Pomegranate peel extract rich } \\
\text { in polyphenols }\end{array}$ & Preliminary report & \multirow{2}{*}{\multicolumn{2}{|c|}{ A promising source of novel agents against COVID-19 }} & {$[115]$} \\
\hline \multicolumn{3}{|l|}{ Flavonoids } & & \\
\hline Baicalein & $\begin{array}{l}\text { Rat model of lung injury } \\
\text { induced by myocardial } \\
\text { ischemia and reperfusion }\end{array}$ & $\begin{array}{l}\text { Reduced histological damage and } \\
\text { apoptosis in the lung; } \\
\text { downregulated IL-6, IL-1, and } \\
\text { TNF- } \alpha\end{array}$ & Attenuation of lung injury & {$[122]$} \\
\hline Luteolin & Murine model & $\begin{array}{l}\text { Suppressed ICAM-1, NF- }-\mathrm{B} \text {, } \\
\text { oxidative stress, iNOS; } \\
\text { Reduced IL- } 6 \text { and IL-1 } 1 \beta \text { in lung } \\
\text { tissue }\end{array}$ & Attenuation of sepsis-induced ALI & {$[123]$} \\
\hline Luteolin & Murine model & $\begin{array}{l}\text { Prevented NF- } \mathrm{KB} \text { activation and } \\
\text { activated } \mathrm{Akt} / \mathrm{Nrf} 2\end{array}$ & $\begin{array}{l}\text { Protection against mercuric } \\
\text { chloride-induced lung injury }\end{array}$ & [124] \\
\hline Hesperidin & $\begin{array}{l}\text { Rat model of lung injury } \\
\text { induced by influenza A }\end{array}$ & $\begin{array}{l}\text { Inhibited cytokine production in } \\
\text { pulmonary microvascular } \\
\text { endothelial cells by suppressing } \\
\text { MAPK }\end{array}$ & Alleviated lung injury & {$[125]$} \\
\hline $\begin{array}{l}\text { Flavonoid-based } \\
\text { phytomedicine caflanone }\end{array}$ & $\begin{array}{l}\text { Molecular docking; in vitro } \\
\text { (Hcov-OC43 human } \\
\text { coronavirus) }\end{array}$ & $\begin{array}{l}\text { Capacity to inhibit the production of } \\
\text { cytokines including IL- } 1 \beta, \text { IL- } 6 \text {, } \\
\text { IL- } 8, \text { Mip- } 1 \alpha, \text { TNF- } \alpha \\
\text { High affinity for spike protein, } \\
\text { helicase, and protease ACE } 2 \text { sites }\end{array}$ & Potential against SARS-CoV-2 & {$[113]$} \\
\hline \multirow[t]{2}{*}{ Hesperidin } & $\begin{array}{l}\text { Mice co-treated with } \\
\text { hesperidin and LPS }\end{array}$ & Decreased IL-33 and TNF- $\alpha$ & $\begin{array}{l}\text { Anti-inflammatory - potential } \\
\text { against SARS-CoV-2 }\end{array}$ & {$[127]$} \\
\hline & $\begin{array}{l}\text { Vero E6 cells, hACE2 } \\
\text { transgenic mice infected } \\
\text { with SARS-CoV-2; } \\
\text { LPS-induced acute lung } \\
\text { injury of mice }\end{array}$ & $\begin{array}{l}\text { Vero E6 cells: inhibited } \\
\text { SARS-CoV-2-induced cell } \\
\text { damage } \\
\text { hACE2 transgenic mice infected } \\
\text { with SARS-CoV-2: LPS-induced } \\
\text { acute lung injury of mice: } \\
\text { inhibited viral replication and } \\
\text { relieved the lung tissue; improved } \\
\text { respiratory function, inhibited } \\
\text { inflammatory cell infiltration in } \\
\text { the lung, decreased IL-1 } \beta \text { and } \\
\text { TNF- } \alpha\end{array}$ & & [128] \\
\hline \multicolumn{5}{|l|}{ Stilbenoids } \\
\hline Resveratrol & $\begin{array}{l}\text { Murine LPS-induced sepsis } \\
\text { model }\end{array}$ & Sirtl activation & Reduction of ALI and inflammation & {$[143]$} \\
\hline $3,5,4^{\prime}$-Tri- $O$-acetylresveratrol & $\begin{array}{l}\text { Model of ALI induced by } \\
\text { seawater inhalation in rats }\end{array}$ & $\begin{array}{c}\text { Inhibited NF-KB and iNOS followed } \\
\text { by decreased NO, TNF- } \alpha, \text { IL- } 1 \beta\end{array}$ & Reduction of ALI & {$[144]$} \\
\hline
\end{tabular}


Table 2 (continued)

\begin{tabular}{|c|c|c|c|c|}
\hline Phenolic compound & Study details & Mechanisms & Effects & Reference \\
\hline Resveratrol & $\begin{array}{l}\text { Vero cells infected with } \\
\text { SARS-CoV-2 }\end{array}$ & \multicolumn{2}{|c|}{$\begin{array}{l}\text { Capacity to inhibit SARS-CoV-2 infection (potential role as a novel } \\
\text { COVID-19 therapeutic) }\end{array}$} & {$[142]$} \\
\hline Resveratrol & $\begin{array}{l}\text { Model of } \mathrm{C} 3 \mathrm{H} / \mathrm{HeJ} \text { mice } \\
\text { with SEB-induced } \\
\text { inflammatory cytokines, } \\
\text { ARDS, and } 100 \% \\
\text { mortality }\end{array}$ & $\begin{array}{l}\text { Altered gut and lung microbiota } \\
\text { (L. reuteri induction) }\end{array}$ & ARDS attenuation & {$[145]$} \\
\hline Resveratrol and pterostilbene & $\begin{array}{l}\text { Primary human bronchial } \\
\text { epithelial cells cultured } \\
\text { under ALI conditions }\end{array}$ & Inhibited SARS-CoV-2 infection & & {$[147]$} \\
\hline \multicolumn{5}{|l|}{ Coumarins } \\
\hline $\begin{array}{l}\text { Sesquiterpene coumarins } \\
\text { from Ferulafukanensis }\end{array}$ & $\begin{array}{l}\text { Murine macrophage-like cell } \\
\text { line RAW264.7 activated } \\
\text { by LPS and recombinant } \\
\text { mouse IFN- } \gamma\end{array}$ & $\begin{array}{l}\text { Inhibited NO, iNOS, IL- } 6 \text {, and } \\
\text { TNF- } \alpha \text { gene expression }\end{array}$ & Anti-inflammatory & {$[153]$} \\
\hline Cichoriin & In silico & Capacity to reach high lung levels & $\begin{array}{l}\text { Suggested potential as a novel } \\
\text { COVID-19 therapeutic }\end{array}$ & {$[156]$} \\
\hline \multicolumn{5}{|l|}{ Traditional herbal medicine } \\
\hline $\mathrm{AE}$ & $\begin{array}{l}\text { PQ-induced pulmonary } \\
\text { fibrosis animal model }\end{array}$ & $\begin{array}{l}\text { Nrf2 activation and } \\
\text { NF- } k B / T G F-\beta 1 / \operatorname{Smad} 2 / 3 \\
\text { inhibition }\end{array}$ & $\begin{array}{l}\text { Protective capacity against } \\
\text { pulmonary fibrosis (lessened the } \\
\text { destruction of lung tissue, reduced } \\
\text { collagen deposition (lung } \\
\text { interstitium), inflammatory } \\
\text { infiltration, and inflammatory } \\
\text { cytokines) }\end{array}$ & {$[160]$} \\
\hline ShufengJiedu & $\begin{array}{l}\text { HCoV-229E murine model } \\
\text { of lung index, viral load in } \\
\text { the lung, the release of } \\
\text { cytokines, and T- and } \\
\text { B-lymphocytes }\end{array}$ & $\begin{array}{l}\text { Decreased IL-6, IL-10, TNF- } \alpha \text {, } \\
\text { IFN- } \gamma \text { in the lung and increased } \\
\text { CD4+ and CD8+ cells in the } \\
\text { blood; reduced NF-kB activity }\end{array}$ & $\begin{array}{l}\text { Anti-inflammatory (potential against } \\
\text { SARS-CoV-2) }\end{array}$ & {$[161]$} \\
\hline $\begin{array}{l}\text { Oral treatment with } \\
\text { Traditional Chinese } \\
\text { medicine decoction } \\
\text { without any other drugs }\end{array}$ & $\begin{array}{l}\text { Case report (61-year-old } \\
\text { female with COVID-19) }\end{array}$ & \multicolumn{2}{|c|}{$\begin{array}{l}\text { Improved lung inflammatory exudate, pulmonary fibrosis, and quality of } \\
\text { life }\end{array}$} & {$[162]$} \\
\hline \multirow[t]{2}{*}{ DSV } & $\begin{array}{l}\text { Model of SARS-CoV-2 } \\
\text { induced inflammation in } \\
\text { the humanized zebrafish } \\
\text { model }\end{array}$ & $\begin{array}{l}\text { Blocked IL- } 6 \text { and TNF- } \alpha \text { cytokine } \\
\text { surge }\end{array}$ & $\begin{array}{l}\text { Anti-inflammatory (pharmacological } \\
\text { activity against SARS-CoV-2 } \\
\text { induced inflammation) }\end{array}$ & {$[163]$} \\
\hline & Murine ALI model & $\begin{array}{l}\text { Regulated the differentiation of } \\
\text { naïve CD4+T cells and activated } \\
\text { IL-10 immune modulation }\end{array}$ & $\begin{array}{l}\text { Alleviated lung injury and } \\
\text { suppressed uncontrolled } \\
\text { inflammation }\end{array}$ & {$[167]$} \\
\hline \multicolumn{5}{|l|}{ Curcumin } \\
\hline Curcumin & $\begin{array}{l}\text { Bleomycin-induced basal } \\
\text { alveolar epithelial cells } \\
\text { and C57BL/6 mice }\end{array}$ & $\begin{array}{l}\text { Suppressed EGFR, Ki67, and lung } \\
\text { fibrosis }\end{array}$ & Alleviated lung fibrosis & {$[168]$} \\
\hline $\begin{array}{l}\text { Solubilized curcumin (direct } \\
\text { pulmonary delivery) }\end{array}$ & $\begin{array}{l}\text { Murine model of lethal } \\
\text { pneumonia (C57BL/6 } \\
\text { mice inoculated with a } \\
\text { lethal dose of Klebsiella } \\
\text { pneumoniae) }\end{array}$ & Decreased TNF- $\alpha$, IFN- $\beta$, NF-kB & $\begin{array}{l}\text { Reduced injury, inflammation, and } \\
\text { mortality }\end{array}$ & [169] \\
\hline $\begin{array}{l}\text { EGYVIR (pepper and } \\
\text { curcumin extract) }\end{array}$ & In silico, in vitro & \multirow[t]{2}{*}{$\begin{array}{l}\text { Modulated NF- } \kappa \text { B/TNF- } \alpha / \text { IL- } 6 \\
\quad(\text { downregulated IL-6 and TNF- } \alpha)\end{array}$} & Potential to decrease cytokine storm & {$[170]$} \\
\hline Hydrazinocurcumin & Computational modeling & & $\begin{array}{l}\text { Immunomodulatory and } \\
\text { anticytokine therapeutic potential }\end{array}$ & {$[171]$} \\
\hline Nanocurcumin & $\begin{array}{l}\text { Randomized, double-blind, } \\
\text { placebo-controlled-mild } \\
(n=40) \text { and severe }(n= \\
\text { 40) COVID-19 patients }\end{array}$ & $\begin{array}{l}\text { Decreased Th17 cells, Th17 } \\
\text { cell-related factors, and levels of } \\
\text { Th17 cell-related cytokines }\end{array}$ & $\begin{array}{l}\text { Potential to improve COVID-19 } \\
\text { patients' inflammatory conditions }\end{array}$ & {$[172]$} \\
\hline $\begin{array}{l}\text { Nanocurcumin oral } \\
\text { formulation }\end{array}$ & $\begin{array}{l}\text { Open-label nonrandomized } \\
\text { clinical trial }\end{array}$ & Improved recovery time & & {$[96]$} \\
\hline
\end{tabular}


Table 2 (continued)

\begin{tabular}{|c|c|c|c|c|}
\hline Phenolic compound & Study details & Mechanisms & Effects & Reference \\
\hline & \multicolumn{4}{|l|}{$\begin{array}{l}\text { Hospitalized patients with } \\
\text { mild-to-moderate } \\
\text { COVID-19, } \\
\text { nano-curcumin }(n=21) \\
\text { and control }(n=20) \text { group }\end{array}$} \\
\hline $\begin{array}{l}\text { Curcumin-piperine } \\
\text { co-supplementation } \\
\text { Nrf2-interacting nutrients }\end{array}$ & Randomized controlled trial & \multicolumn{2}{|c|}{$\begin{array}{l}\text { Introduced protocol for the trial (evaluation of disease duration, severity, } \\
\text { and clinical symptoms) }\end{array}$} & {$[173]$} \\
\hline Nrf2-interacting nutrients & $\begin{array}{l}\text { Modulation of endoplasmic r } \\
\text { theACE-angiotensin-II-AT }\end{array}$ & $\begin{array}{l}\text { ticulum stress and the } \\
\mathrm{IR} \text { axis }\end{array}$ & $\begin{array}{l}\text { Capacity to mitigate COVID-19 } \\
\text { severity }\end{array}$ & {$[174]$} \\
\hline
\end{tabular}

Abbreviations: ACE, angiotensin-converting enzyme; AE, Arenaria kansuensis ethanol extract; Akt, protein kinase B; ALI, acute lung injury; AT1R, angiotensin II receptor type 1; COPD, chronic obstructive pulmonary disease; COX-2, cyclooxygenase-2; CS, cigarette smoke; DSV, Divya-SwasariVati; EGFR, epidermal growth factor receptor; ET, elastase; ICAM-1, intercellular adhesion molecule; IFN- $\gamma$, interferon $\gamma$; IL, interleukin; iNOS, inducible nitric oxide synthase; LPS, lipopolysaccharide; MAPK, mitogen-activated protein kinase; MD2, myeloid differentiation protein 2; Mip-1 $\alpha$, macrophage inflammatory protein $1 \alpha$; NF- $\mathrm{kB}$, nuclear factor- $\mathrm{kB}$; NO, nitric oxide; Nrf2, nuclear factor erythroid 2-related factor 2; PGE-2, prostaglandin E2; PQ, paraquat; TGF- $\beta 1$, transforming growth factor $\beta 1$; TLR4, Toll-like receptor 4

revealed its capacity to significantly improve recovery time in hospitalized patients [96]. In addition, Miryan et al. have introduced a protocol for a randomized controlled trial to evaluate the capacity of curcumin-piperine co-supplementation on disease duration, severity, and clinical symptoms, and inflammatory mediators in COVID-19 patients [173].

Last but not least, specific Nrf2-interacting nutrients reveals a promising potential against COVID-19 [174]. Genetic or pharmacological Nrf2 activation is associated with anti-inflammatory and antiviral efficacy in various pathologies while targeting specific cysteine receptors within KEAP1 is considered as the most relevant mechanism of such action. Although the potential effects of Nrf2 inducers for the reduction of oxidative stress and inflammation in COVID-19 is not fully elucidated yet, it can be hypothesized that phenolic compounds could reduce COVID-19 severity via the activation of Nrf2 and subsequentmodulation of inflammatory and immune processes [51, 77]. Nrf2-interacting nutrients (berberine, curcumin, epigallocatechin gallate, genistein, quercetin, resveratrol, sulforaphane) reduce insulin resistance, endothelial damage, lung injury, and cytokine storm and act on several mechanisms such as mTOR, PPAR $\gamma, \mathrm{NF}-\mathrm{kB}$, ERK, etc. Nrf2interacting nutrients can promote the mitigation of COVID-19 severity through the endoplasmic reticulum stress, ACEangiotensin-II-AT1R axis (AT1R). Indeed, geographical areas with very low COVID-19 mortality are those with the lowest prevalence of obesity and intake of fermented food associated with Nrf2 activation (sub-Saharan Africa, Asia, Central Europe) [174].

In conclusion, apart from the most known classes of phenolics, other plant species (Curcuma longa) or specific phytochemicals characterized as Nrf2-interacting nutrients of the phenolic structure shows a potential to be effective modulators of inflammatory and immune pathways associated with COVID-19 and related organ damage.

Table 2 provides a detailed overview of current research on the anti-inflammatory and immunomodulatory properties and the overview of the most current in silico, molecular docking screening, and clinical trials evaluating the effects of plant phenolics that can be utilizable also in the search for novel treatment modalities against lung damage induced by COVID-19.

\section{Conclusions and future perspectives in the framework of 3PM}

Naturally occurring plant substances have long been considered as effective helpers in maintaining good physical and mental shape against health adverse effects of different origin. Phytochemicals - both native ones in the intact plants and their extracts or pharmacologic derivatives show a wide range of health-protective systemic effects. To this end, anti-inflammatory, immunomodulatory, and organ-protective effects of plant phenolic compounds are promising for protective treatments under the COVID-19 pandemic condition.

More specifically, plant phenolics (phenolic acids, flavonoids, coumarins, stilbenoids) pleiotropic activity modulates inflammatory mediators (IL-6, TNF- $\alpha$ ), oxidative stress, and specific signaling cascades (NF-KB, Nrf2 among others) that is utilized by searching for effective compounds against COVID-19 infection and cascading complications such as cytokine storm, systemic inflammation and associated organ damage. Corresponding protective effects are evidencebased as demonstrated in the current paper.

Caution! Although in preclinical studies natural phytochemicals demonstrate evidence-based effects against 


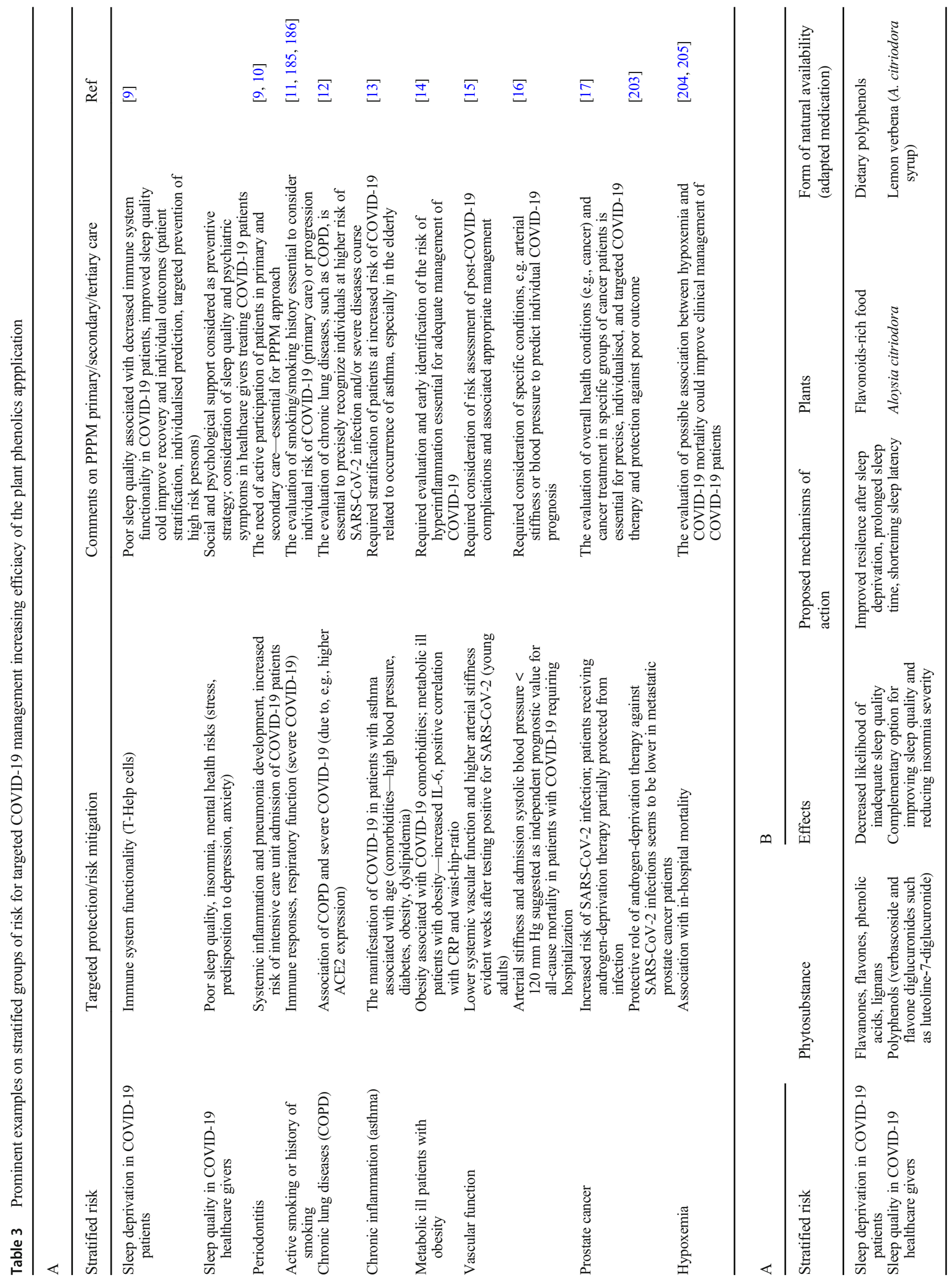




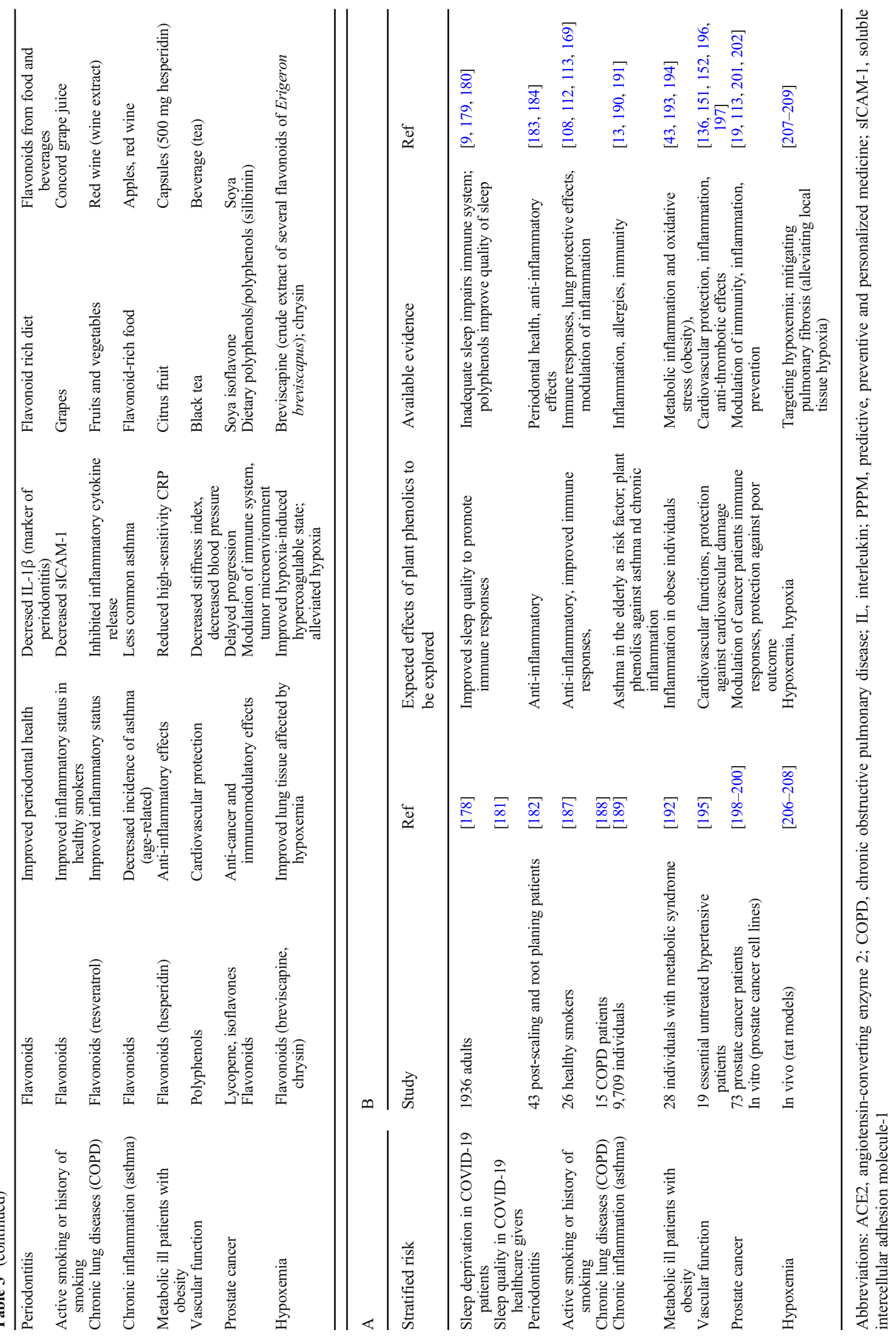




\section{NATURALLY OCCURING PLANT PHENOLIC COMPOUNDS}

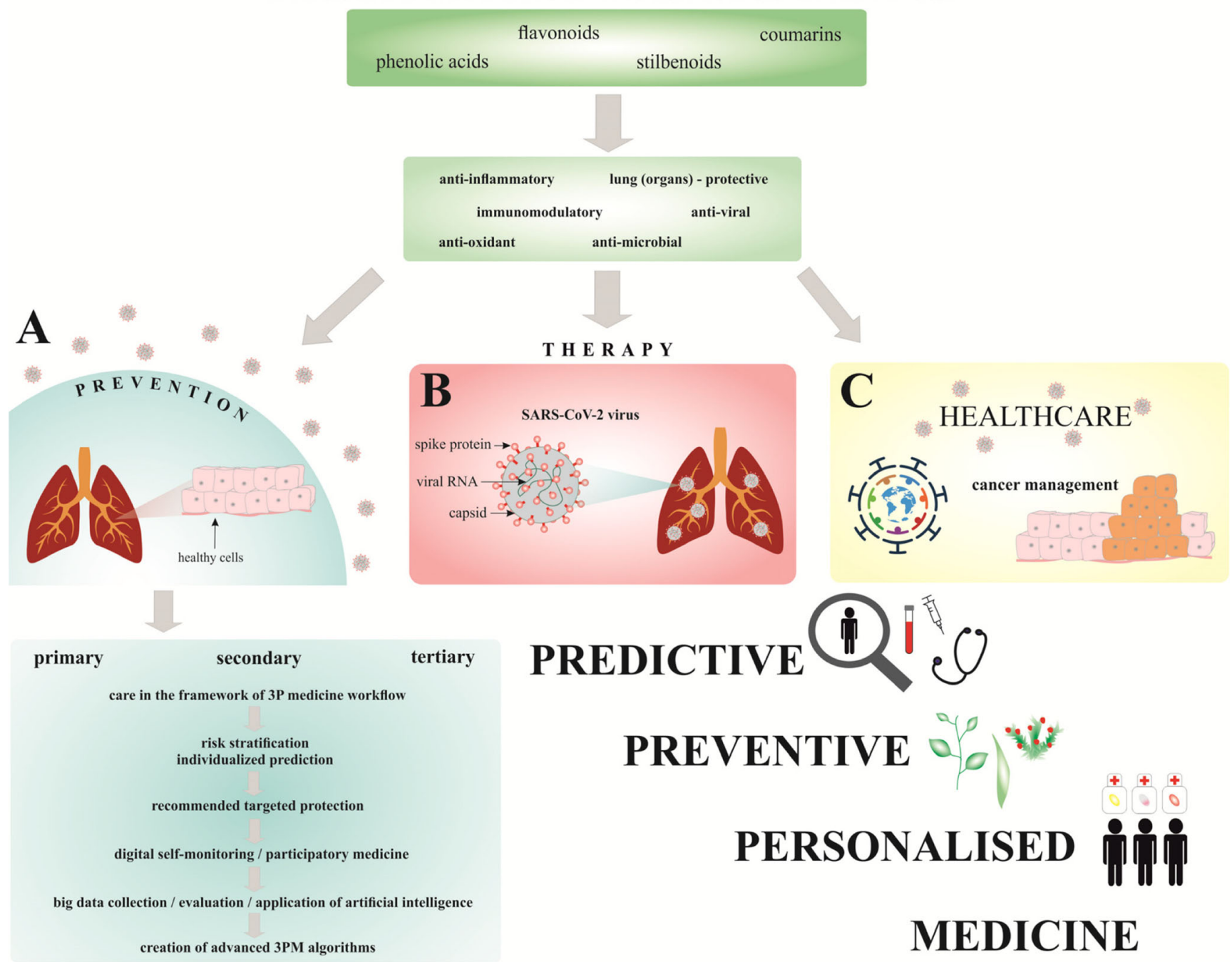

Fig. 3 Application of plant phenolics to mitigate COVID-19-associated systemic damage in the framework of 3PM

SARS-CoV-2 infection and organ damage, the consumption of unproven and unapproved products is a great health risk to be avoided by consultating accrediated specialists in the area.

In order to promote clinically relevant research and facilitate cost-effective treatments in the close future, Table 3 summarizes prominent examples of stratified patient groups, corresponding risks and mitigating measures presenting evidence-based molecular and cellualr mechanisms as well as expected health effects. To mitigate corresponding risks in primary, secondary and tertiary care, phytoprotection has to be targeted to the stratified patients groups avoiding potential negative side effects and increasing the oveall treatment efficacy. Figure 3 summarizes general concepts in the framework of predictive, preventive, and personalized medicine (3PM) [175-177].

Author contribution A.L., P.K., and O.G. were responsible for the paper conception and final data presentation. The manuscript was drafted by
A.L., M.S. (Marek Samec), L.K., and critically revised by P.K., E.K., K.B., K.Z., M.Š., B.A., M.S. (Manaal Siddiqui) and S. T.S. H. Figures were prepared by M.S. (Marek Samec), L.K., and A.L.

P.K., O.G., and D.B. provided skilled assistance and supervised the overall preparation of the manuscript. All authors have read and agreed to the published version of the manuscript.

Funding Open Access funding enabled and organized by Projekt DEAL. The present study was supported by the Scientific Grant Agency of the Ministry of Education, Science, Research and Sport of the Slovak Republic (Bratislava, Slovak Republic; grant no. VEGA 1/0136/19), Slovak Research and Development Agency under Contract No. APVV-16-0021, and by the LISPER project (grant Nr. 313011V446) in bilateral agreement with the European Association for Predictive, Preventive and Personalised Medicine. D. B. was supported by a National Priorities Research Program grant (NPRP 11S-1214-170101) from the Qatar National Research Fund (QNRF, a member of Qatar Foundation).

Data availability Not applicable.

Code availability Not applicable. 


\section{Declarations}

Ethics approval Not applicable.

Consent to participate Not applicable.

Consent for publication Not applicable.

Conflict of interest The authors declare no competing interests.

Open Access This article is licensed under a Creative Commons Attribution 4.0 International License, which permits use, sharing, adaptation, distribution and reproduction in any medium or format, as long as you give appropriate credit to the original author(s) and the source, provide a link to the Creative Commons licence, and indicate if changes were made. The images or other third party material in this article are included in the article's Creative Commons licence, unless indicated otherwise in a credit line to the material. If material is not included in the article's Creative Commons licence and your intended use is not permitted by statutory regulation or exceeds the permitted use, you will need to obtain permission directly from the copyright holder. To view a copy of this licence, visit http://creativecommons.org/licenses/by/4.0/.

\section{References}

1. Skladany L, Koller T, Adamcova Selcanova S, Vnencakova J, Jancekova D, Durajova V, et al. Challenging management of severe chronic disorders in acute pandemic situation: chronic liver disease under COVID-19 pandemic as the proof-of-principle model to orchestrate the measures in 3PM context. EPMA J. 2021;12(1):1-14. https://doi.org/10.1007/s13167-021-00231-8.

2. Grech G, Zhan X, Yoo BC, Bubnov R, Hagan S, Danesi R, et al. EPMA position paper in cancer: current overview and future perspectives. EPMA J. 2015;6:9. https://doi.org/10.1186/s13167015-0030-6.

3. Theoharides TC, Conti P. COVID-19 and multisystem inflammatory syndrome, or is it mast cell activation syndrome? J Biol Regul Homeost Agents. 2020;34:1633-6. https://doi.org/10.23812/20EDIT3.

4. Sampson V, Kamona N, Sampson A. Could there be a link between oral hygiene and the severity of SARS-CoV-2 infections? Br Dent J. 2020;228:971-5. https://doi.org/10.1038/s41415-020$1747-8$.

5. Xiang Z, Koo H, Chen Q, Zhou X, Liu Y, Simon-Soro A. Potential implications of SARS-CoV-2 oral infection in the host microbiota. J Oral Microbiol. 2020;13:1853451. https://doi.org/ $10.1080 / 20002297.2020 .1853451$.

6. Botros N, Iyer P, Ojcius DM. Is there an association between oral health and severity of COVID-19 complications? Biom J. 2020;43:325-7. https://doi.org/10.1016/j.bj.2020.05.016.

7. Baindara P, Chakraborty R, Holliday ZM, Mandal SM, Schrum AG. Oral probiotics in coronavirus disease 2019: connecting the gut-lung axis to viral pathogenesis, inflammation, secondary infection and clinical trials. New Microbes New Infect. 2021;40: 100837. https://doi.org/10.1016/j.nmni.2021.100837.

8. Tachalov V, Orechova L, Kudriavtseva T, Loboda E, Pachkoria M, Berezkina I, Golubnitschaja O. Making a complex dental care tailored to the person: population health in focus of predictive, preventive and personalised (3P) medical approach. EPMA J $2021 ; 12$ (2):1-12. https://doi.org/10.1007/s13167-021-00240-7.
9. Richter K, Kellner S, Hillemacher T, Golubnitschaja O. Sleep quality and COVID-19 outcomes: the evidence-based lessons in the framework of predictive, preventive and personalised (3P) medicine. EPMA J. 2021;12(2):1-21. https://doi.org/10.1007/ s13167-021-00245-2.

10. Marouf N, Cai W, Said KN, Daas H, Diab H, Chinta VR, et al. Association between periodontitis and severity of COVID-19 infection: a case-control study. J Clin Periodontol. 2021;48:483-91. https://doi.org/10.1111/jcpe.13435.

11. Haddad C, Bou Malhab S, Sacre H, Salameh P. Smoking and COVID-19: a scoping review. Tob Use Insights. 2021;14:1-9. https://doi.org/10.1177/1179173X21994612.

12. Lee SC, Son KJ, Han CH, Park SC, Jung JY. Impact of COPD on COVID-19 prognosis: a nationwide population-based study in South Korea. Sci Rep. 2021;11:3735. https://doi.org/10.1038/ s41598-021-83226-9.

13. Izquierdo JL, Almonacid C, González Y, Del Rio-Bermudez C, Ancochea J, Cárdenas R, et al. The impact of COVID-19 on patients with asthma. Eur Respir J. 2021;57:2003142. https://doi. org/10.1183/13993003.03142-2020.

14. Chiappetta S, Sharma AM, Bottino V, Stier C. COVID-19 and the role of chronic inflammation in patients with obesity. Int $\mathrm{J}$ Obes. 2020;44:1790-2. https://doi.org/10.1038/s41366-020-0597-4.

15. Ratchford SM, Stickford JL, Province VM, Stute N, Augenreich MA, Koontz LK, et al. Vascular alterations among young adults with SARS-CoV-2. Am J Physiol Heart Circ Physiol. 2021;320: H404-10. https://doi.org/10.1152/ajpheart.00897.2020.

16. Rodilla E, López-Carmona MD, Cortes X, Cobos-Palacios L, Canales S, Sáez MC, et al. Impact of arterial stiffness on allcause mortality in patients hospitalized with COVID-19 in Spain. Hypertension. 2021;77:856-67. https://doi.org/10.1161/ HYPERTENSIONAHA.120.16563.

17. Montopoli M, Zumerle S, Vettor R, Rugge M, Zorzi M, Catapano $\mathrm{CV}$, et al. Androgen-deprivation therapies for prostate cancer and risk of infection by SARS-CoV-2: a population-based study $(\mathrm{N}=$ 4532). Ann Oncol. 2020;31:1040-5. https://doi.org/10.1016/j. annonc.2020.04.479.

18. Muchtaridi M, Fauzi M, Khairul Ikram NK, Mohd Gazzali A, Wahab HA. Natural flavonoids as potential angiotensinconverting enzyme 2 inhibitors for anti-SARS-CoV-2. Molecules. 2020;25(17):3980. https://doi.org/10.3390/molecules25173980.

19. Liskova A, Samec M, Koklesova L, Samuel SM, Zhai K, Al-Ishaq RK, et al. Flavonoids against the SARS-CoV-2 Induced Inflammatory Storm. Biomed Pharmacother. 2021;138:111430. https://doi.org/10.1016/j.biopha.2021.111430.

20. Abotaleb M, Samuel SM, Varghese E, Varghese S, Kubatka P, Liskova A, Büsselberg D. Flavonoids in cancer and apoptosis. Cancers (Basel) 2018;11(1):28. https://doi.org/10.3390/ cancers11010028.

21. Zakaryan H, Arabyan E, Oo A, Zandi K. Flavonoids: promising natural compounds against viral infections. Arch Virol. 2017;162: 2539-51. https://doi.org/10.1007/s00705-017-3417-y.

22. Wang L, Song J, Liu A, Xiao B, Li S, Wen Z, et al. Research progress of the antiviral bioactivities of natural flavonoids. Nat Prod Bioprospect. 2020;10:271-83. https://doi.org/10.1007/ s13659-020-00257-x.

23. Wu Y-H, Zhang B-Y, Qiu L-P, Guan R-F, Ye Z-H, Yu X-P. Structure properties and mechanisms of action of naturally originated phenolic acids and their derivatives against human viral infections. Curr Med Chem. 2017;24:4279-302. https://doi.org/ 10.2174/0929867324666170815102917.

24. Ikeda K, Nishide M, Tsujimoto K, Nagashima S, Kuwahara T, Mitani T, et al. Antiviral and virucidal activities of umesu phenolics on influenza viruses. Jpn J Infect Dis. 2020;73:8-13. https:// doi.org/10.7883/yoken.JJID.2018.522. 
25. Loaiza-Cano V, Monsalve-Escudero LM, Filho C, da SMB, Martinez-Gutierrez M, De Sousa DP. Antiviral role of phenolic compounds against dengue virus: a review. Biomolecules. 2020: 11(1):11. https://doi.org/10.3390/biom11010011.

26. Solnier J, Fladerer J-P. Flavonoids: a complementary approach to conventional therapy of COVID-19? Phytochem Rev. 2020:1-23. https://doi.org/10.1007/s11101-020-09720-6.

27. Haridas M, Sasidhar V, Nath P, Abhithaj J, Sabu A, Rammanohar P. Compounds of Citrus medica and Zingiber officinale for COVID-19 inhibition: in silico evidence for cues from Ayurveda. Futur J Pharm Sci. 2021;7:13. https://doi.org/10. 1186/s43094-020-00171-6.

28. Patel A, Rajendran M, Shah A, Patel H, Pakala SB, Karyala P. Virtual screening of curcumin and its analogs against the spike surface glycoprotein of SARS-CoV-2 and SARS-CoV. J Biomol Struct Dyn. 2021:1-9. https://doi.org/10.1080/07391102.2020. 1868338.

29. Kumar B, Zaidi S, Haque S, Dasgupta N, Hussain A, Unni S, et al. In silico studies reveal antiviral effects of traditional indian spices on COVID-19. Curr Pharm Des. 2020. https://doi.org/10.2174/ 1381612826666201223095548

30. Shih W-L, Fang C-T, Chen P-J. Anti-viral treatment and cancer control. Recent Results Cancer Res. 2014;193:269-90. https://doi. org/10.1007/978-3-642-38965-8 14.

31. Šudomová M, Hassan STS. Nutraceutical curcumin with promising protection against herpesvirus infections and their associated inflammation: mechanisms and pathways. Microorganisms. 2021;9. https://doi.org/10.3390/microorganisms9020292.

32. Šudomová M, Berchová-Bímová K, Marzocco S, Liskova A, Kubatka P, Hassan STS. Berberine in human oncogenic herpesvirus infections and their linked cancers. Viruses. 2021;13:1014. https://doi.org/10.3390/v13061014.

33. Wu Y-H. Naturally derived anti-hepatitis B virus agents and their mechanism of action. World J Gastroenterol. 2016;22:188-204. https://doi.org/10.3748/wjg.v22.i1.188.

34. Wu C-C, Fang C-Y, Cheng Y-J, Hsu H-Y, Chou S-P, Huang S-Y, et al. Inhibition of Epstein-Barr virus reactivation by the flavonoid apigenin. J Biomed Sci. 2017;24. https://doi.org/10.1186/s12929016-0313-9.

35. Lin D, Xiao M, Zhao J, Li Z, Xing B, Li X, et al. An overview of plant phenolic compounds and their importance in human nutrition and management of type 2 diabetes. Molecules. 2016;21. https://doi.org/10.3390/molecules21101374.

36. Saibabu V, Fatima Z, Khan LA, Hameed S. Therapeutic potential of dietary phenolic acids. Adv Pharmacol Sci. 2015;2015. https:// doi.org/10.1155/2015/823539.

37. Su X, Zhang J, Wang H, Xu J, He J, Liu L, et al. Phenolic acid profiling, antioxidant, and anti-inflammatory activities, and MiRNA regulation in the polyphenols of 16 blueberry samples from China. Molecules. 2017;22. https://doi.org/10.3390/ molecules22020312.

38. Cheng J, Yi X, Chen H, Wang Y, He X. Anti-inflammatory phenylpropanoids and phenolics from Ficus hirta Vahl. Fitoterapia. 2017;121:229-34. https://doi.org/10.1016/j.fitote. 2017.07.018

39. Ginwala R, Bhavsar R, Chigbu DGI, Jain P, Khan ZK. Potential role of flavonoids in treating chronic inflammatory diseases with a special focus on the anti-inflammatory activity of apigenin. Antioxidants (Basel). 2019:8. https://doi.org/10.3390/ antiox 8020035

40. Yixi X, Weijie Y, Fen T, Xiaoqing C, Licheng R. Antibacterial activities of flavonoids: structure-activity relationship and mechanism. Curr Med Chem. 2014;22:132-49.

41. Mandal SM, Dias RO, Franco OL. Phenolic compounds in antimicrobial therapy. J Med Food. 2017;20:1031-8. https://doi.org/ 10.1089/jmf.2017.0017.
42. Gálvez Ranilla L, Christopher A, Sarkar D, Shetty K, Chirinos R, Campos D. Phenolic composition and evaluation of the antimicrobial activity of free and bound phenolic fractions from a Peruvian purple corn (Zea mays L.) Accession. J Food Sci. 2017;82:2968 76. https://doi.org/10.1111/1750-3841.13973.

43. Zairi A, Nouir S. M Hamdi, N.; Bennani, M.; Bergaoui, I.; Mtiraoui, A.; Chaouachi, M.; Trabelsi, M. Antioxidant, antimicrobial and the phenolic content of infusion, decoction and methanolic extracts of thyme and rosmarinus species. Curr Pharm Biotechnol. 2018;19:590-9. https://doi.org/10. 2174/1389201019666180817141512.

44. Li Y, Zhang T, Chen GY. Flavonoids and colorectal cancer prevention. Antioxidants (Basel). 2018:7. https://doi.org/10.3390/ antiox 7120187.

45. Espín JC, González-Sarrías A, Tomás-Barberán FA. The gut microbiota: a key factor in the therapeutic effects of (poly)phenols. Biochem Pharmacol. 2017;139:82-93. https://doi.org/10.1016/j. bcp.2017.04.033.

46. Kumar Singh A, Cabral C, Kumar R, Ganguly R, Kumar Rana H, Gupta A, et al. Beneficial effects of dietary polyphenols on gut microbiota and strategies to improve delivery efficiency. Nutrients. 2019;11. https://doi.org/10.3390/nu11092216.

47. Fernández-Rojas B, Gutiérrez-Venegas G. Flavonoids exert multiple periodontic benefits including anti-inflammatory, periodontal ligament-supporting, and alveolar bone-preserving effects. Life Sci. 2018;209:435-54. https://doi.org/10.1016/j.lfs.2018.08.029.

48. Dimbath E, Maddipati V, Stahl J, Sewell K, Domire Z, George S, et al. Implications of microscale lung damage for COVID-19 pulmonary ventilation dynamics: a narrative review. Life Sci. 2021;274:119341. https://doi.org/10.1016/j.lfs.2021.119341.

49. Frizzelli A, Tuttolomondo D, Aiello M, Majori M, Bertorelli G, Chetta A. What happens to people's lungs when they get coronavirus disease 2019? Acta Biomed. 2020;91:146-9. https://doi.org/ 10.23750/abm.v91i2.9574.

50. El-Shahat RA, El-Demerdash RS, El Sherbini ES, Saad EA. HClinduced acute lung injury: a study of the curative role of mesenchymal stem/stromal cells and cobalt protoporphyrin. J Genet Eng Biotechnol. 2021;19:41. https://doi.org/10.1186/s43141-02100139-w.

51. Cuadrado A, Pajares M, Benito C, Jiménez-Villegas J, Escoll M, Fernández-Ginés R, et al. Can activation of NRF2 be a strategy against COVID-19? Trends Pharmacol Sci. 2020;41:598-610. https://doi.org/10.1016/j.tips.2020.07.003.

52. Batah SS, Fabro AT. Pulmonary pathology of ARDS in COVID19: a pathological review for clinicians. Respir Med. 2021;176: 106239. https://doi.org/10.1016/j.rmed.2020.106239.

53. Carsana L, Sonzogni A, Nasr A, Rossi RS, Pellegrinelli A, Zerbi $\mathrm{P}$, et al. Pulmonary post-mortem findings in a series of COVID-19 cases from Northern Italy: a two-centre descriptive study. Lancet Infect Dis. 2020;20:1135-40. https://doi.org/10.1016/S14733099(20)30434-5.

54. Mauad T, Duarte-Neto AN, da Silva LFF, de Oliveira EP, de Brito JM, do Nascimento ECT, et al. Tracking the time course of pathological patterns of lung injury in severe COVID-19. Respir Res. 2021;22:32. https://doi.org/10.1186/s12931-021-01628-9.

55. Mason RJ. Pathogenesis of COVID-19 from a cell biology perspective. Eur Respir J. 2020;55. https://doi.org/10.1183/ 13993003.00607-2020.

56. Doglioni C, Ravaglia C, Chilosi M, Rossi G, Dubini A, Pedica F, et al. Covid-19 interstitial pneumonia: histological and immunohistochemical features on cryobiopsies. RES. 2021:1-11. https:// doi.org/10.1159/000514822.

57. McGonagle D, Bridgewood C, Ramanan AV, Meaney JFM, Watad A. COVID-19 vasculitis and novel vasculitis mimics. The Lancet Rheumatology. 2021;3:e224-33. https://doi.org/10. 1016/S2665-9913(20)30420-3. 
58. Chen W, Pan JY. Anatomical and pathological observation and analysis of SARS and COVID-19: microthrombosis is the main cause of death. Biol Proced Online. 2021;23. https://doi.org/10. 1186/s12575-021-00142-y.

59. Gustine JN, Jones D. Immunopathology of Hyperinflammation in COVID-19. Am J Pathol. 2021;191:4-17. https://doi.org/10.1016/ j.ajpath.2020.08.009.

60. Roshanravan N, Seif F, Ostadrahimi A, Pouraghaei M, Ghaffari S. Targeting cytokine storm to manage patients with COVID-19: a mini-review. Arch Med Res. 2020. https://doi.org/10.1016/j. arcmed.2020.06.012.

61. Kandasamy M. NF-KB signalling as a pharmacological target in COVID-19: potential roles for IKK $\beta$ inhibitors. Naunyn Schmiedeberg's Arch Pharmacol. 2021:1-7. https://doi.org/10. 1007/s00210-020-02035-5.

62. Hariharan A, Hakeem AR, Radhakrishnan S, Reddy MS, Rela M. The role and therapeutic potential of NF-kappa-b pathway in severe COVID-19 patients. Inflammopharmacology. 2020:1-10. https://doi.org/10.1007/s10787-020-00773-9.

63. Leng L, Cao R, Ma J, Mou D, Zhu Y, Li W, et al. Pathological features of COVID-19-associated lung injury: a preliminary proteomics report based on clinical samples. Signal Transduction and Targeted Therapy. 2020;5:1-9. https://doi.org/10.1038/s41392020-00355-9.

64. Ueland T, Holter J, Holten A, Müller K, Lind A, Bekken G, et al Distinct and early increase in circulating MMP-9 in COVID-19 patients with respiratory failure. J Inf Secur. 2020;81:e41-3. https://doi.org/10.1016/j.jinf.2020.06.061.

65. Satarker S, Tom AA, Shaji RA, Alosious A, Luvis M, Nampoothiri M. JAK-STAT pathway inhibition and their implications in COVID-19 therapy. Postgrad Med. 2020:1-19. https:// doi.org/10.1080/00325481.2020.1855921.

66. Solimani F, Meier K, Ghoreschi K. Janus kinase signaling as risk factor and therapeutic target for severe SARS-CoV-2 infection. Eur J Immunol. 2021. https://doi.org/10.1002/eji.202149173.

67. Grimes JM, Grimes KV. P38 MAPK inhibition: a promising therapeutic approach for COVID-19. J Mol Cell Cardiol. 2020;144: 63-5. https://doi.org/10.1016/j.yjmcc.2020.05.007.

68. Laforge M, Elbim C, Frère C, Hémadi M, Massaad C, Nuss P, et al. Tissue damage from neutrophil-induced oxidative stress in COVID-19. Nat Rev Immunol. 2020;20:515-6. https://doi.org/10. 1038/s41577-020-0407-1.

69. Hoxha M. What about COVID-19 and arachidonic acid pathway? Eur J Clin Pharmacol. 2020:1-4. https://doi.org/10.1007/s00228020-02941-w.

70. Spadaro S, Fogagnolo A, Campo G, Zucchetti O, Verri M, Ottaviani I, et al. Markers of endothelial and epithelial pulmonary injury in mechanically ventilated COVID-19 ICU patients. Crit Care. 2021;25:74. https://doi.org/10.1186/s13054-021-03499-4.

71. Costela-Ruiz VJ, Illescas-Montes R, Puerta-Puerta JM, Ruiz C, Melguizo-Rodríguez L. SARS-CoV-2 infection: the role of cytokines in COVID-19 disease. Cytokine Growth Factor Rev. 2020;54:62-75. https://doi.org/10.1016/j.cytogfr.2020.06.001.

72. Pieretti JC, Rubilar O, Weller RB, Tortella GR, Seabra AB. Nitric oxide (NO) and nanoparticles - potential small tools for the war against COVID-19 and other human coronavirus infections. Virus Res. 2021;291:198202. https://doi.org/10.1016/j.virusres.2020. 198202.

73. Guimarães L, Rossini CVT, Lameu C. Implications of SARSCov-2 infection on ENOS and INOS activity: consequences for the respiratory and vascular systems. Nitric Oxide. 2021. https:// doi.org/10.1016/j.niox.2021.04.003.

74. Majnooni MB, Fakhri S, Shokoohinia Y, Kiyani N, Stage K, Mohammadi P, et al. Phytochemicals: potential therapeutic interventions against coronavirus-associated lung injury. Front
Pharmacol. 2020;11:588467. https://doi.org/10.3389/fphar.2020. 588467.

75. Matsuyama T, Kubli SP, Yoshinaga SK, Pfeffer K, Mak TW. An aberrant STAT pathway is central to COVID-19. Cell Death Differ. 2020;27:3209-25. https://doi.org/10.1038/s41418-02000633-7.

76. Huang Q, Wu X, Zheng X, Luo S, Xu S, Weng J. Targeting inflammation and cytokine storm in COVID-19. Pharmacol Res. 2020;159:105051. https://doi.org/10.1016/j.phrs.2020.105051.

77. Mendonca P, Soliman KFA. Flavonoids activation of the transcription factor Nrf2 as a hypothesis approach for the prevention and modulation of SARS-CoV-2 infection severity. Antioxidants. 2020;9. https://doi.org/10.3390/antiox9080659.

78. Desterke C, Turhan AG, Bennaceur-Griscelli A, Griscelli F. PPAR $\gamma$ cistrome repression during activation of lung monocytemacrophages in severe COVID-19. iScience. 2020;23:101611. https://doi.org/10.1016/j.isci.2020.101611.

79. Shahidi F, Yeo J. Bioactivities of phenolics by focusing on suppression of chronic diseases: a review. Int J Mol Sci. 2018;19. https://doi.org/10.3390/ijms19061573.

80. Kumar N, Goel N. Phenolic Acids: Natural versatile molecules with promising therapeutic applications. Biotechnol Rep (Amst). 2019:24. https://doi.org/10.1016/j.btre.2019.e00370.

81. Abu Khalaf R, Alhusban AA, Al-Shalabi E, Al-Sheikh I, Sabbah DA. Chapter 10 - Isolation and structure elucidation of bioactive polyphenols. In Studies in Natural Products Chemistry; Atta-urRahman, Ed. Bioactive Natural Products; Elsevier. 2019;63:267337.

82. Vuolo MM, Lima VS, Maróstica Junior MR. Chapter 2 - Phenolic compounds: structure, classification, and antioxidant power. In: Campos MRS, editor. In Bioactive Compounds: Woodhead Publishing; 2019. p. 33-50. ISBN 978-0-12-814774-0.

83. Abotaleb M, Liskova A, Kubatka P, Büsselberg D. Therapeutic potential of plant phenolic acids in the treatment of cancer. Biomolecules. 2020;10. https://doi.org/10.3390/biom10020221.

84. Liskova A, Koklesova L, Samec M, Smejkal K, Samuel SM, Varghese E, et al. Flavonoids in cancer metastasis. Cancers (Basel). 2020:12. https://doi.org/10.3390/cancers12061498.

85. Ashrafizadeh M, Ahmadi Z, Farkhondeh T, Samarghandian S. Autophagy as a molecular target of quercetin underlying its protective effects in human diseases. Arch Physiol Biochem. 2019:19. https://doi.org/10.1080/13813455.2019.1671458.

86. Ashrafizadeh M, Tavakol S, Ahmadi Z, Roomiani S, Mohammadinejad R, Samarghandian S. Therapeutic effects of kaempferol affecting autophagy and endoplasmic reticulum stress. Phytother Res. 2020;34:911-23. https://doi.org/10.1002/ ptr.6577.

87. Reinisalo M, Kårlund A, Koskela A, Kaarniranta K, Karjalainen RO. Polyphenol stilbenes: molecular mechanisms of defence against oxidative stress and aging-related diseases. Oxidative Med Cell Longev. 2015;2015. https://doi.org/10.1155/2015/ 340520.

88. Olivas-Aguirre M, Torres-López L, Pottosin I, Dobrovinskaya O. Phenolic compounds cannabidiol, curcumin and quercetin cause mitochondrial dysfunction and suppress acute lymphoblastic leukemia cells. Int J Mol Sci. 2020;22. https://doi.org/10.3390/ ijms22010204.

89. Hewlings SJ, Kalman DS. Curcumin: a review of its' effects on human health. Foods. 2017;6. https://doi.org/10.3390/ foods6100092.

90. Tsao R. Chemistry and biochemistry of dietary polyphenols. Nutrients. 2010;2:1231-46. https://doi.org/10.3390/nu2121231.

91. Ashrafizadeh M, Rafiei H, Mohammadinejad R, Afshar EG, Farkhondeh T, Samarghandian S. Potential therapeutic effects of curcumin mediated by JAK/STAT signaling pathway: a review. 
Phytother Res. 2020, 1745;34:-1760. https://doi.org/10.1002/ptr. 6642.

92. Kapinova A, Stefanicka P, Kubatka P, Zubor P, Uramova S, Kello $\mathrm{M}$, et al. Are plant-based functional foods better choice against cancer than single phytochemicals? A critical review of current breast cancer research. Biomed Pharmacother. 2017;96:1465-77. https://doi.org/10.1016/j.biopha.2017.11.134.

93. Liskova A, Kubatka P, Samec M, Zubor P, Mlyncek M, Bielik T, et al. Dietary phytochemicals targeting cancer stem cells. Molecules. 2019;24. https://doi.org/10.3390/molecules24050899.

94. Niu W-H, Wu F, Cao W-Y, Wu Z-G, Chao Y-C, Liang C. Network pharmacology for the identification of phytochemicals in traditional Chinese medicine for COVID-19 that may regulate interleukin-6. Biosci Rep. 2021;41. https://doi.org/10.1042/ BSR20202583.

95. Placha D, Jampilek J. Chronic inflammatory diseases, antiinflammatory agents and their delivery nanosystems. Pharmaceutics. 2021;13. https://doi.org/10.3390/ pharmaceutics13010064

96. Saber-Moghaddam N, Salari S, Hejazi S, Amini M, Taherzadeh Z, Eslami S, et al. Oral nano-curcumin formulation efficacy in management of mild to moderate hospitalized coronavirus disease-19 patients: an open label nonrandomized clinical trial. Phytother Res. 2021. https://doi.org/10.1002/ptr.7004.

97. Aiello P, Consalvi S, Poce G, Raguzzini A, Toti E, Palmery M, et al. Dietary flavonoids: nano delivery and nanoparticles for cancer therapy. Semin Cancer Biol. 2019. https://doi.org/10.1016/j. semcancer.2019.08.029.

98. Peñalva R, Morales J, González-Navarro CJ, Larrañeta E, Quincoces G, Peñuelas I, et al. Increased oral bioavailability of resveratrol by its encapsulation in casein nanoparticles. Int J Mol Sci. 2018;19. https://doi.org/10.3390/ijms19092816.

99. Chimento A, De Amicis F, Sirianni R, Sinicropi MS, Puoci F, Casaburi I, et al. Progress to improve oral bioavailability and beneficial effects of resveratrol. Int J Mol Sci. 2019;20. https://doi.org/ 10.3390/ijms20061381.

100. Yahfoufi N, Alsadi N, Jambi M, Matar C. The immunomodulatory and anti-inflammatory role of polyphenols. Nutrients. 2018;10. https://doi.org/10.3390/nu10111618.

101. Ashrafizadeh M, Ahmadi Z, Mohammadinejad R, Ghasemipour Afshar E. Tangeretin: a mechanistic review of its pharmacological and therapeutic effects. J Basic Clin Physiol Pharmacol. 2020;31. https://doi.org/10.1515/jbcpp-2019-0191.

102. Liskova A, Koklesova L, Samec M, Varghese E, Abotaleb M, Samuel SM, et al. Implications of flavonoids as potential modulators of cancer neovascularity. J Cancer Res Clin Oncol. 2020. https://doi.org/10.1007/s00432-020-03383-8.

103. Kapinova A, Kubatka P, Liskova A, Baranenko D, Kruzliak P, Matta M, et al. Controlling metastatic cancer: the role of phytochemicals in cell signaling. J Cancer Res Clin Oncol. 2019;145: 1087-109. https://doi.org/10.1007/s00432-019-02892-5.

104. He Y-Q, Zhou C-C, Yu L-Y, Wang L, Deng J, Tao Y-L, et al. Natural product derived phytochemicals in managing acute lung injury by multiple mechanisms. Pharmacol Res. 2021;163: 105224. https://doi.org/10.1016/j.phrs.2020.105224.

105. BenSaad LA, Kim KH, Quah CC, Kim WR, Shahimi M. Antiinflammatory potential of ellagic acid, gallic acid and Punicalagin A\&B isolated from Punica granatum. BMC Complement Altern Med. 2017;17. https://doi.org/10.1186/s12906-017-1555-0.

106. Chu Q, Yu X, Jia R, Wang Y, Zhang Y, Zhang S, et al. Flavonoids from Apios americana Medikus leaves protect RAW264.7 cells against Inflammation via Inhibition of MAPKs, Akt-MTOR pathways, and Nfr2 activation. Oxidative Med Cell Longev. 2019: 1563024. https://doi.org/10.1155/2019/1563024.

107. Huang L, Hou L, Xue H, Wang C. Gallic acid inhibits inflammatory response of RAW264.7 macrophages by blocking the activation of TLR4/NF-kB induced by LPS. Xi Bao Yu Fen Zi Mian Yi Xue Za Zhi. 2016;32:1610-4.

108. Singla E, Dharwal V, Naura AS. Gallic acid protects against the COPD-linked lung inflammation and emphysema in mice. Inflamm Res. 2020;69:423-34. https://doi.org/10.1007/s00011020-01333-1.

109. Chen L, Jin Y, Chen H, Sun C, Fu W, Zheng L, et al. Discovery of caffeic acid phenethyl ester derivatives as novel myeloid differentiation protein 2 inhibitors for treatment of acute lung injury. Eur J Med Chem. 2018;143:361-75. https://doi.org/10.1016/j.ejmech. 2017.11.066.

110. Zhang X, Li C, Li J, Xu Y, Guan S, Zhao M. Protective effects of protocatechuic acid on acute lung injury induced by lipopolysaccharide in mice via P38MAPK and NF-KB signal pathways. Int Immunopharmacol. 2015;26:229-36. https://doi.org/10.1016/j. intimp.2015.03.031.

111. Umar HI, Siraj B, Ajayi A, Jimoh TO, Chukwuemeka PO. Molecular docking studies of some selected gallic acid derivatives against five non-structural proteins of novel coronavirus. J Genet Eng Biotechnol. 2021;19. https://doi.org/10.1186/s43141-02100120-7.

112. Alrasheid AA, Babiker MY, Awad TA. Evaluation of certain medicinal plants compounds as new potential inhibitors of novel corona virus (COVID-19) using molecular docking analysis. In Silico Pharmacol. 2021;9:10. https://doi.org/10.1007/s40203020-00073-8.

113. Ngwa W, Kumar R, Thompson D, Lyerly W, Moore R, Reid T-E, et al. Potential of flavonoid-inspired phytomedicines against COVID-19. Molecules. 2020;25. https://doi.org/10.3390/ molecules 25112707

114. Adem S, Eyupoglu V, Sarfraz I, Rasul A, Zahoor AF, Ali M, et al. Caffeic acid derivatives (CAFDs) as inhibitors of SARS-CoV-2: CAFDs-based functional foods as a potential alternative approach to combat COVID-19. Phytomedicine. 2021;85:153310. https:// doi.org/10.1016/j.phymed.2020.153310.

115. Tito A, Colantuono A, Pirone L, Pedone E, Intartaglia D, Giamundo G, et al. A Pomegranate peel extract as inhibitor of SARS-CoV-2 spike binding to human ACE2 (in vitro): a promising source of novel antiviral drugs. bioRxiv. 2020:406116. https://doi.org/10.1101/2020.12.01.406116.

116. Fei J, Liang B, Jiang C, Ni H, Wang L. Luteolin inhibits IL- $1 \beta$-induced inflammation in rat chondrocytes and attenuates osteoarthritis progression in a rat model. Biomed Pharmacother. 2019;109:1586-92. https://doi.org/10.1016/j. biopha.2018.09.161.

117. Guo H, Li M, Xu L-J. Apigetrin treatment attenuates LPS-induced acute otitis media though suppressing inflammation and oxidative stress. Biomed Pharmacother. 2019;109:1978-87. https://doi.org/ 10.1016/j.biopha.2018.07.022.

118. Salaverry LS, Parrado AC, Mangone FM, Dobrecky CB, Flor SA, Lombardo $\mathrm{T}$, et al. In vitro anti-inflammatory properties of Smilax campestris aqueous extract in human macrophages, and characterization of its flavonoid profile. J Ethnopharmacol. 2020;247: 112282. https://doi.org/10.1016/j.jep.2019.112282.

119. Jung UJ, Cho Y-Y, Choi M-S. Apigenin ameliorates dyslipidemia, hepatic steatosis and insulin resistance by modulating metabolic and transcriptional profiles in the liver of high-fat diet-induced obese mice. Nutrients. 2016;8. https://doi.org/10.3390/ nu8050305.

120. Sassi A, Mokdad Bzéouich I, Mustapha N, Maatouk M, Ghedira $\mathrm{K}$, Chekir-Ghedira L. Immunomodulatory potential of hesperetin and chrysin through the cellular and humoral response. Eur J Pharmacol. 2017;812:91-6. https://doi.org/10.1016/j.ejphar. 2017.07.017.

121. Zaragozá C, Villaescusa L, Monserrat J, Zaragozá F, ÁlvarezMon M. Potential Therapeutic anti-inflammatory and 
immunomodulatory effects of dihydroflavones, flavones, and flavonols. Molecules. 2020;25:1017. https://doi.org/10.3390/ molecules25041017.

122. Lai C-C, Huang P-H, Yang A-H, Chiang S-C, Tang C-Y, Tseng $\mathrm{K}-\mathrm{W}$, et al. Baicalein attenuates lung injury induced by myocardial ischemia and reperfusion. Am J Chin Med. 2017;45:791-811. https://doi.org/10.1142/S0192415X17500422.

123. Rungsung S, Singh TU, Rabha DJ, Kumar T, Cholenahalli Lingaraju M, Parida S, et al. Luteolin attenuates acute lung injury in experimental mouse model of sepsis. Cytokine. 2018;110:33343. https://doi.org/10.1016/j.cyto.2018.03.042.

124. Liu B, Yu H, Baiyun R, Lu J, Li S, Bing Q, et al. Protective effects of dietary luteolin against mercuric chloride-induced lung injury in mice: involvement of AKT/Nrf2 and NF-KB pathways. Food Chem Toxicol. 2018;113:296-302. https://doi.org/10.1016/j.fct. 2018.02.003.

125. Ding Z, Sun G, Zhu Z. Hesperidin attenuates influenza A virus (H1N1) induced lung injury in rats through its anti-inflammatory effect. Antivir Ther. 2018;23:611-5. https://doi.org/10.3851/ IMP3235.

126. Bellavite P, Donzelli A. Hesperidin and SARS-CoV-2: new light on the healthy function of citrus fruits. Antioxidants (Basel). 2020: 9. https://doi.org/10.3390/antiox9080742.

127. Al-Rikabi R, Al-Shmgani H, Dewir YH, El-Hendawy S. In vivo and in vitro evaluation of the protective effects of hesperidin in lipopolysaccharide-induced inflammation and cytotoxicity of cell. Molecules (Basel, Switzerland). 2020;25. https://doi.org/10.3390/ molecules25030478.

128. Song J, Zhang L, Xu Y, Yang D, Zhang L, Yang S, et al. The comprehensive study on the therapeutic effects of baicalein for the treatment of COVID-19 in vivo and in vitro. Biochem Pharmacol. 2021;183:114302. https://doi.org/10.1016/j.bcp.2020.114302.

129. Zandi K, Musall K, Oo A, Cao D, Liang B, Hassandarvish P, et al. Baicalein and baicalin inhibit SARS-CoV-2 RNA-dependentRNA polymerase. Microorganisms. 2021;9. https://doi.org/10. 3390/microorganisms 9050893.

130. Su H, Yao S, Zhao W, Li M, Liu J, Shang W, et al. Anti-SARS$\mathrm{CoV}-2$ activities in vitro of Shuanghuanglian preparations and bioactive ingredients. Acta Pharmacol Sin. 2020;41:1167-77. https://doi.org/10.1038/s41401-020-0483-6.

131. Bai C, Li T, Sun Q, Xin Q, Xu T, Yu J, et al. Protective effect of baicalin against severe burn-induced remote acute lung injury in rats. Mol Med Rep. 2018;17:2689-94. https://doi.org/10.3892/ mmr.2017.8120.

132. Liu T, Dai W, Li C, Liu F, Chen Y, Weng D, et al. Baicalin alleviates silica-induced lung inflammation and fibrosis by inhibiting the Th17 response in C57BL/6 mice. J Nat Prod. 2015;78:3049-57. https://doi.org/10.1021/acs.jnatprod.5b00868.

133. Peng L-Y, Yuan M, Song K, Yu J-L, Li J-H, Huang J-N, et al. Baicalin alleviated APEC-induced acute lung injury in chicken by inhibiting NF-KB pathway activation. Int Immunopharmacol. 2019;72:467-72. https://doi.org/10.1016/j.intimp.2019.04.046.

134. Meng X, Hu L, Li W. Baicalin ameliorates lipopolysaccharideinduced acute lung injury in mice by suppressing oxidative stress and inflammation via the activation of the Nrf2-mediated HO-1 signaling pathway. Naunyn Schmiedeberg's Arch Pharmacol. 2019;392:1421-33. https://doi.org/10.1007/s00210-019-01680-9.

135. Li L, Bao H, Wu J, Duan X, Liu B, Sun J, et al. Baicalin is antiinflammatory in cigarette smoke-induced inflammatory models in vivo and in vitro: a possible role for HDAC2 activity. Int Immunopharmacol. 2012;13:15-22. https://doi.org/10.1016/j. intimp.2012.03.001.

136. Zhang Z, Zhang X, Bi K, He Y, Yan W, Yang CS, et al. Potential protective mechanisms of green tea polyphenol EGCG against COVID-19. Trends Food Sci Technol. 2021;114:11-24. https:// doi.org/10.1016/j.tifs.2021.05.023.
137. Eräsalo H, Hämäläinen M, Leppänen T, Mäki-Opas I, Laavola M, Haavikko R, et al. Natural stilbenoids have anti-inflammatory properties in vivo and down-regulate the production of inflammatory mediators NO, IL6, and MCP1 possibly in a PI3K/Akt-dependent manner. J Nat Prod. 2018;81:1131-42. https://doi.org/10. 1021/acs.jnatprod.7b00384.

138. Akinwumi BC, Bordun K-AM, Anderson HD. Biological activities of stilbenoids. Int J Mol Sci. 2018;19. https://doi.org/10.3390/ ijms 19030792 .

139. Dvorakova M, Landa P. Anti-inflammatory activity of natural stilbenoids: a review. Pharmacol Res. 2017;124:126-45. https:// doi.org/10.1016/j.phrs.2017.08.002.

140. Chhabra G, Singh CK, Amiri D, Akula N, Ahmad N. Recent advancements on immunomodulatory mechanisms of resveratrol in tumor microenvironment. Molecules. 2021;26. https://doi.org/ 10.3390/molecules26051343.

141. Mattio LM, Catinella G, Pinto A, Dallavalle S. Natural and natureinspired stilbenoids as antiviral agents. Eur J Med Chem. 2020;202:112541. https://doi.org/10.1016/j.ejmech.2020.112541.

142. Yang M, Wei J, Huang T, Lei L, Shen C, Lai J, et al. Resveratrol inhibits the replication of severe acute respiratory syndrome coronavirus 2 (SARS-CoV-2) in cultured vero cells. Phytother Res. 2020. https://doi.org/10.1002/ptr.6916.

143. Li T, Zhang J, Feng J, Li Q, Wu L, Ye Q, et al. Resveratrol reduces acute lung injury in a LPS-induced sepsis mouse model via activation of Sirt1. Mol Med Rep. 2013;7:1889-95. https://doi.org/10. 3892/mmr.2013.1444.

144. Ma L, Chen X, Wang R, Duan H, Wang L, Liang L, et al. 3,5,4' Tri-O-acetylresveratrol decreases seawater inhalation-induced acute lung injury by interfering with the NF-KB and i-NOS pathways. Int J Mol Med. 2016;37:165-72. https://doi.org/10.3892/ ijmm.2015.2403.

145. Alghetaa H, Mohammed A, Zhou J, Singh N, Nagarkatti M, Nagarkatti P. Resveratrol-mediated attenuation of superantigendriven acute respiratory distress syndrome is mediated by microbiota in the lungs and gut. Pharmacol Res. 2021;167:105548. https://doi.org/10.1016/j.phrs.2021.105548.

146. Alazmi M, Motwalli O. Molecular basis for drug repurposing to study the interface of the s protein in SARS-CoV-2 and human ACE2 through docking, characterization, and molecular dynamics for natural drug candidates. J Mol Model. 2020;26:338. https:// doi.org/10.1007/s00894-020-04599-8.

147. ter Ellen BM, Kumar ND, Bouma EM, Troost B, van de Pol DPI, van der Ende-Metselaar HH, et al. Resveratrol and pterostilbene potently inhibit SARS-CoV-2 replication in vitro. bioRxiv. 2021: 285940. https://doi.org/10.1101/2020.09.24.285940.

148. Gangadevi S, Badavath VN, Thakur A, Yin N, De Jonghe S, Acevedo O, et al. Kobophenol A inhibits binding of host ACE2 receptor with spike RBD domain of SARS-CoV-2, a lead compound for blocking COVID-19. J Phys Chem Lett. 17931802;2021:12. https://doi.org/10.1021/acs.jpclett.0c03119.

149. Cho H, Park J-H, Ahn E-K, Oh JS. Kobophenol A isolated from roots of Caragana sinica (Buc'hoz) Rehder exhibits antiinflammatory activity by regulating NF-KB nuclear translocation in J774A.1 cells. Toxicol Rep. 2018;5:647-53. https://doi.org/10. 1016/j.toxrep.2018.05.011.

150. Pereira TM, Franco DP, Vitorio F, Kummerle AE. Coumarin compounds in medicinal chemistry: some important examples from the last years. Curr Top Med Chem. 2018;18:124-48. https://doi. org/10.2174/1568026618666180329115523.

151. Stefanachi A, Leonetti F, Pisani L, Catto M, Carotti A. Coumarin: a natural, privileged and versatile scaffold for bioactive compounds. Molecules. 2018;23. https://doi.org/10.3390/ molecules23020250.

152. Nayeli M-B, Maribel H-R, Enrique J-F, Rafael B-P, Margarita AF, Macrina F-M, et al. Anti-inflammatory activity of coumarins 
isolated from Tagetes lucida Cav. Nat Prod Res. 2020;34:3244-8. https://doi.org/10.1080/14786419.2018.1553172.

153. Motai T, Daikonya A, Kitanaka S. Sesquiterpene coumarins from Ferula fukanensis and their pro-inflammatory cytokine gene expression inhibitory effects. Chem Pharm Bull (Tokyo). 2013;61: 618-23. https://doi.org/10.1248/cpb.c12-01028.

154. Maurya AK, Mishra N. In silico validation of coumarin derivatives as potential inhibitors against main protease, NSP10/NSP16methyltransferase, phosphatase and endoribonuclease of SARS CoV-2. J Biomol Struct Dyn. 2020:1-16. https://doi.org/10. 1080/07391102.2020.1808075.

155. Nejabat M, Ghodsi R, Hadizadeh F. Coumarins and quinolones as effective multiple targeted agents versus Covid-19: an in silico study. Med Chem. 2021. https://doi.org/10.2174/ 1573406417666210208223924 .

156. Rivero-Segura NA, Gomez-Verjan JC. In silico screening of natural products isolated from Mexican herbal medicines against COVID-19. Biomolecules. 2021;11. https://doi.org/10.3390/ biom11020216.

157. Chidambaram S, El-Sheikh MA, Alfarhan AH, Radhakrishnan S, Akbar I. Synthesis of novel coumarin analogues: investigation of molecular docking interaction of SARS-CoV-2 Proteins with natural and synthetic coumarin analogues and their pharmacokinetics studies. Saudi J Biol Sci. 2021;28:1100-8. https://doi.org/10. 1016/j.sjbs.2020.11.038.

158. Huang Y-F, Bai C, He F, Xie Y, Zhou H. Review on the potential action mechanisms of chinese medicines in treating coronavirus disease 2019 (COVID-19). Pharmacol Res. 2020;158:104939. https://doi.org/10.1016/j.phrs.2020.104939.

159. Balkrishna A, Verma S, Sharma P, Tomer M, Srivastava J, Varshney A. Comprehensive and rapid quality evaluation method for the Ayurvedic medicine Divya-Swasari-Vati using two analytical techniques: UPLC/QToF MS and HPLC-DAD. Pharmaceuticals (Basel). 2021:14. https://doi.org/10.3390/ ph14040297.

160. Cui Y, Xin H, Tao Y, Mei L, Wang Z. Arenaria kansuensis attenuates pulmonary fibrosis in mice via the activation of Nrf2 pathway and the inhibition of NF-KB/TGF-Beta1/Smad2/3 pathway. Phytother Res. 2021;35:974-86. https://doi.org/10.1002/ptr.6857.

161. XIA L, SHI Y, Su J, Friedemann T, Tao Z, Lu Y, et al. Shufeng Jiedu, a promising herbal therapy for moderate COVID-19: antiviral and anti-inflammatory properties, pathways of bioactive compounds, and a clinical real-world pragmatic study. Phytomedicine. 2020. https://doi.org/10.1016/j.phymed.2020. 153390.

162. Zhi N, Mo Q, Yang S, Qin Y, Chen H, Wu Z, et al. Treatment of pulmonary fibrosis in one convalescent patient with corona virus disease 2019 by oral traditional Chinese medicine decoction: a case report. J Integr Med. 2021;19:185-90. https://doi.org/10. 1016/j.joim.2020.11.005.

163. Balkrishna A, Verma S, Solleti SK, Khandrika L, Varshney A. Calcio-herbal medicine Divya-Swasari-Vati ameliorates SARSCoV-2 spike protein-induced pathological features and inflammation in humanized zebrafish model by moderating IL- 6 and TNF$\alpha$ cytokines. J Inflamm Res. 2020;13:1219-43. https://doi.org/10. 2147/JIR.S286199.

164. Kunnumakkara AB, Bordoloi D, Padmavathi G, Monisha J, Roy NK, Prasad S, et al. Curcumin, the golden nutraceutical: multitargeting for multiple chronic diseases. Br J Pharmacol. 2017;174:1325-48. https://doi.org/10.1111/bph.13621.

165. Phumsuay R, Muangnoi C, Dasuni Wasana PW, Hasriadi H, Vajragupta $\mathrm{O}$, Rojsitthisak $\mathrm{P}$, et al. Molecular insight into the anti-inflammatory effects of the curcumin ester prodrug curcumin diglutaric acid in vitro and in vivo. IJMS. 2020;21:5700. https:// doi.org/10.3390/ijms21165700.
166. Shin SA, Joo BJ, Lee JS, Ryu G, Han M, Kim WY, et al. Phytochemicals as anti-inflammatory agents in animal models of prevalent inflammatory diseases. Molecules. 2020;25. https://doi. org/10.3390/molecules25245932.

167. Chai Y-S, Chen Y-Q, Lin S-H, Xie K, Wang C-J, Yang Y-Z, et al. Curcumin regulates the differentiation of naïve $\mathrm{CD} 4+\mathrm{T}$ cells and activates IL-10 immune modulation against acute lung injury in mice. Biomed Pharmacother. 2020;125:109946. https://doi.org/ 10.1016/j.biopha.2020.109946.

168. Shaikh SB, Prabhu A, Bhandary YP. Curcumin Suppresses epithelial growth factor receptor (EGFR) and proliferative protein (Ki 67 ) in acute lung injury and lung fibrosis in vitro and in vivo. Endocr Metab Immune Disord Drug Targets. 2020;20:558-63. https://doi.org/10.2174/1871530319666190823160230.

169. Zhang B, Swamy S, Balijepalli S, Panicker S, Mooliyil J, Sherman MA, et al. Direct pulmonary delivery of solubilized curcumin reduces severity of lethal pneumonia. FASEB J. 2019;33:13294 309. https://doi.org/10.1096/fj.201901047RR.

170. Roshdy WH, Rashed HA, Kandeil A, Mostafa A, Moatasim Y, Kutkat O, et al. EGYVIR: an immunomodulatory herbal extract with potent antiviral activity against SARS-CoV-2. PLoS One. 2020;15:e0241739. https://doi.org/10.1371/journal.pone. 0241739 .

171. Noor H, Ikram A, Rathinavel T, Kumarasamy S, Nasir Iqbal M, Bashir Z. Immunomodulatory and anti-cytokine therapeutic potential of curcumin and its derivatives for treating COVID-19 - a computational modeling. J Biomol Struct Dyn. 2021:1-16. https:// doi.org/10.1080/07391102.2021.1873190.

172. Tahmasebi S, El-Esawi MA, Mahmoud ZH, Timoshin A, Valizadeh H, Roshangar L, et al. Immunomodulatory effects of nanocurcumin on Th17 cell responses in mild and severe COVID19 patients. J Cell Physiol. 2021;236:5325-38. https://doi.org/10. $1002 /$ jcp.30233.

173. Miryan M, Bagherniya M, Sahebkar A, Soleimani D, Rouhani $\mathrm{MH}$, Iraj B, et al. Effects of curcumin-piperine co-supplementation on clinical signs, duration, severity, and inflammatory factors in patients with COVID-19: a structured summary of a study protocol for a randomised controlled trial. Trials. 2020;21:1027. https:// doi.org/10.1186/s13063-020-04924-9.

174. Bousquet J, Cristol J-P, Czarlewski W, Anto JM, Martineau A, Haahtela T, et al. Nrf2-interacting nutrients and COVID-19: time for research to develop adaptation strategies. Clin Transl Allergy. 2020;10:58. https://doi.org/10.1186/s13601-020-00362-7.

175. Ahluwalia P, Ahluwalia M, Vaibhav K, Mondal A, Sahajpal N, Islam $\mathrm{S}$, et al. Infections of the lung: a predictive, preventive and personalized perspective through the lens of evolution, the emergence of SARS-CoV-2 and its pathogenesis. EPMA J. 2020;11(4):1-21. https://doi.org/10.1007/s13167-020-00230-1.

176. Radanliev P, De Roure D, Walton R, Van Kleek M, Montalvo RM, Santos O, et al. COVID-19 what have we learned? The rise of social machines and connected devices in pandemic management following the concepts of predictive, preventive and personalized medicine. EPMA J. 2020;11(3):311-32. https://doi.org/10.1007/ s13167-020-00218-x.

177. Crigna AT, Samec M, Koklesova L, Liskova A, Giordano FA, Kubatka P, et al. Cell-free nucleic acid patterns in disease prediction and monitoring-hype or hope? EPMA J. 2020;11(4):1-25. https://doi.org/10.1007/s13167-020-00226-x.

178. Godos J, Ferri R, Castellano S, Angelino D, Mena P, Del Rio D, et al. Specific dietary (poly)phenols are associated with sleep quality in a cohort of Italian adults. Nutrients. 2020;12. https://doi.org/ 10.3390/nu12051226.

179. de Silva E, S. ME, Ono BHVS, Souza JC. Sleep and immunity in times of COVID-19. Rev Assoc Med Bras (1992). 2020;66(Suppl 2):143-7. https://doi.org/10.1590/1806-9282.66.S2.143. 
180. Zick SM, Wright BD, Sen A, Arnedt JT. Preliminary examination of the efficacy and safety of a standardized chamomile extract for chronic primary insomnia: a randomized placebo-controlled pilot study. BMC Complement Altern Med. 2011;11:78. https://doi. org/10.1186/1472-6882-11-78.

181. Afrasiabian F, Mirabzadeh Ardakani M, Rahmani K, Azadi NA, Alemohammad ZB, Bidaki R, et al. Aloysia citriodora Palau (lemon verbena) for insomnia patients: a randomized, double-blind, placebo-controlled clinical trial of efficacy and safety. Phytother Res. 2019;33:350-9. https://doi.org/10.1002/ptr.6228.

182. Sparrow TV, Dodington DW, Yumol JL, Fritz PC, Ward WE. Higher intakes of flavonoids are associated with lower salivary IL- $1 \beta$ and maintenance of periodontal health 3-4 years after scaling and root planing. J Clin Periodontol. 2020;47:461-9. https:// doi.org/10.1111/jepe.13263.

183. Balci Yuce H, Toker H, Yildirim A, Tekin MB, Gevrek F, Altunbas N. The effect of luteolin in prevention of periodontal disease in Wistar rats. J Periodontol. 2019;90:1481-9. https:// doi.org/10.1002/JPER.18-0584.

184. Gutiérrez-Venegas G, Kawasaki-Cárdenas P, Arroyo-Cruz SR, Maldonado-Frías S. Luteolin inhibits lipopolysaccharide actions on human gingival fibroblasts. Eur J Pharmacol. 2006;541:95105. https://doi.org/10.1016/j.ejphar.2006.03.069.

185. Gülsen A, Yigitbas BA, Uslu B, Drömann D, Kilinc O. The effect of smoking on COVID-19 symptom severity: systematic review and meta-analysis. Pulm Med. 2020;2020:7590207. https://doi. org/10.1155/2020/7590207.

186. Patanavanich R, Glantz SA. Smoking Is associated with COVID19 progression: a meta-analysis. Nicotine Tob Res. 2020;22: 1653-6. https://doi.org/10.1093/ntr/ntaa082.

187. Kokkou E, Siasos G, Georgiopoulos G, Oikonomou E, Verveniotis A, Vavuranakis M, et al. The impact of dietary flavonoid supplementation on smoking-induced inflammatory process and fibrinolytic impairment. Atherosclerosis. 2016;251:26672. https://doi.org/10.1016/j.atherosclerosis.2016.06.054.

188. Culpitt SV, Rogers DF, Fenwick PS, Shah P, Matos CD, Russell REK, et al. Inhibition by red wine extract, resveratrol, of cytokine release by alveolar macrophages in COPD. Thorax. 2003;58:9426. https://doi.org/10.1136/thorax.58.11.942.

189. Shaheen SO, Sterne JA, Thompson RL, Songhurst CE, Margetts BM, Burney PG. Dietary antioxidants and asthma in adults: populationbased case-control study. Am J Respir Crit Care Med. 2001;164: 1823-8. https://doi.org/10.1164/ajrccm.164.10.2104061.

190. Tanaka T, Takahashi R. Flavonoids and asthma. Nutrients. 2013;5:2128-43. https://doi.org/10.3390/nu5062128.

191. Mattioli V, Zanolin ME, Cazzoletti L, Bono R, Cerveri I, Ferrari M, et al. Dietary flavonoids and respiratory diseases: a population-based multi-case-control study in Italian adults. Public Health Nutr. 2020;23: 2548-56. https://doi.org/10.1017/S1368980019003562.

192. Rizza S, Muniyappa R, Iantorno M, Kim J, Chen H, Pullikotil P, et al. Citrus polyphenol hesperidin stimulates production of nitric oxide in endothelial cells while improving endothelial function and reducing inflammatory markers in patients with metabolic syndrome. J Clin Endocrinol Metab. 2011;96:E782-92. https:// doi.org/10.1210/jc.2010-2879.

193. Boccellino M, D'Angelo S. Anti-obesity effects of polyphenol intake: current status and future possibilities. Int J Mol Sci. 2020;21. https://doi.org/10.3390/ijms21165642.

194. Luque-Sierra A, Alvarez-Amor L, Kleemann R, Martín F, Varela LM. Extra-virgin olive oil with natural phenolic content exerts an anti-inflammatory effect in adipose tissue and attenuates the severity of atherosclerotic lesions in Ldlr-/-Leiden mice. Mol Nutr Food Res. 2018;62:e1800295. https://doi.org/10.1002/mnfr.201800295.
195. Grassi D, Draijer R, Desideri G, Mulder T, Ferri C. Black tea lowers blood pressure and wave reflections in fasted and postprandial conditions in hypertensive patients: a randomised study. Nutrients. 2015;7:1037-51. https://doi.org/10.3390/nu7021037.

196. Jiang F, Dusting GJ. Natural Phenolic compounds as cardiovascular therapeutics: potential role of their antiinflammatory effects. Curr Vasc Pharmacol. 2003;1:135-56. https://doi.org/10.2174/ 1570161033476736 .

197. Lutz M, Fuentes E, Ávila F, Alarcón M, Palomo I. Roles of phenolic compounds in the reduction of risk factors of cardiovascular diseases. Molecules. 2019;24. https://doi.org/10.3390/ molecules24020366.

198. Vaishampayan U, Hussain M, Banerjee M, Seren S, Sarkar FH, Fontana $\mathrm{J}$, et al. Lycopene and soy isoflavones in the treatment of prostate cancer. Nutr Cancer. 2007;59:1-7. https://doi.org/10. 1080/01635580701413934.

199. Ting H, Deep G, Kumar S, Jain AK, Agarwal C, Agarwal R. Beneficial effects of the naturally occurring flavonoid silibinin on the prostate cancer microenvironment: role of monocyte chemotactic protein-1 and immune cell recruitment. Carcinogenesis. 2016;37:589-99. https://doi.org/10.1093/carcin/bgw039.

200. Ahn-Jarvis, J.H.; Parihar, A.; Doseff, A.I. Dietary flavonoids for immunoregulation and cancer: food design for targeting disease. Antioxidants (Basel) 2019, 8, doi:https://doi.org/10.3390/antiox8070202.

201. Liskova A, Samec M, Koklesova L, Brockmueller A, Zhai K, Abdellatif B, et al. Flavonoids as an effective sensitizer for anticancer therapy: insights into multi-faceted mechanisms and applicability towards individualized patient profiles. EPMA J. 2021;12(2):1-22. https://doi.org/10.1007/s13167-021-00242-5.

202. Samec M, Liskova A, Koklesova L, Samuel SM, Murin R, Zubor $\mathrm{P}$, et al. The role of plant-derived natural substances as immunomodulatory agents in carcinogenesis. J Cancer Res Clin Oncol. 2020;146:3137-54. https://doi.org/10.1007/s00432-020-03424-2.

203. Caffo O, Gasparro D, Di Lorenzo G, Volta AD, Guglielmini P, Zucali P, et al. Incidence and outcomes of severe acute respiratory syndrome coronavirus 2 infection in patients with metastatic castration-resistant prostate cancer. Eur J Cancer. 2020;140:140 6. https://doi.org/10.1016/j.ejca.2020.09.018.

204. Xie J, Covassin N, Fan Z, Singh P, Gao W, Li G, et al. Association between hypoxemia and mortality in patients with COVID-19. Mayo Clin Proc. 2020;95:1138-47. https://doi.org/10.1016/j. mayocp.2020.04.006.

205. Fisher HK. Hypoxemia in COVID-19 patients: an hypothesis. Med Hypotheses. 2020;143:110022. https://doi.org/10.1016/j. mehy.2020.110022.

206. Gao J, Chen G, He H, Liu C, Xiong X, Li J, et al. Therapeutic effects of breviscapine in cardiovascular diseases: a review. Front Pharmacol. 2017;8. https://doi.org/10.3389/fphar.2017.00289.

207. Huang J-G, Xie M, Zhang X, He Q-Y, He G-Y. Hypoxemia induced the changing structure of the lung tissue in SD rat though changing blood clotting and the effects of breviscapine's intervention. Sichuan Da Xue Xue Bao Yi Xue Ban. 2014;45:567-71 622.

208. Kseibati MO, Sharawy MH, Salem HA. Chrysin mitigates bleomycininduced pulmonary fibrosis in rats through regulating inflammation, oxidative stress, and hypoxia. Int Immunopharmacol. 2020;89: 107011. https://doi.org/10.1016/j.intimp.2020.107011.

209. Neukam K, Stahl W, Tronnier H, Sies H, Heinrich U. Consumption of flavanol-rich cocoa acutely increases microcirculation in human skin. Eur J Nutr. 2007;46:53-6. https://doi.org/ 10.1007/s00394-006-0627-6.

Publisher's note Springer Nature remains neutral with regard to jurisdictional claims in published maps and institutional affiliations. 